\title{
Liberty and Property in the Supreme Court: A Defense of Roth and Perry
}

\author{
Peter N. Simon $\dagger$
}

The due process clauses of the Constitution require procedural protection if the government deprives an individual of "life, liberty, or property." The Supreme Court might have defined "life, liberty, or property" broadly, as one commentator has suggested, as "a unitary concept embracing all interests valued by sensible men."2 Under this definition, virtually any governmental deprivation would implicate one of the due process clauses. Instead, the Court has chosen to give these terms fairly narrow definition, thereby limiting the range of governmental activities subject to judicial supervision under the due process clauses.

This definitional process, at least with regard to "property," began with the 1972 cases of Board of Regents v. Roth ${ }^{3}$ and Perry $v$. Sindermann. ${ }^{4}$ In Roth, the Court held that government benefits are fourteenth amendment "property" only when the recipient has a legitimate expectation, grounded in state law, that he will continue receiving such benefits. In Perry, the Court lield that where sucli a substantive property right to a government benefit is established, the courts, not the legislature creating the right, have the final word on the constitutional need for and sufficiency of the procedural protections afforded it. The Perry-Roth doctrime can be stated succinctly: legislatures create property, and courts protect it.

In the cases raising similar issues that have followed $R$ oth and Perry, the Court has adhered to that formulation with remarkable con-

$\dagger$ Associate Professor of Law, University of Colorado School of Law. B.S. 1962, M.D. 1966, University of Wisconsin; J.D. 1970, Boalt Hall School of Law, University of California, Berkeley.

I would like to thank Dean Betsy Levin and Professors Howard Klemme, Robert Nagel, and Stephen Williams for their helpful comments and suggestions. I an particularly grateful to my colleague Al Alschuler for his painstaking, exhaustive, and helpful coinnicnts on the manuscript and to my friend Tom Brown for his confidence, encouragement, and support.

1. U.S. ConsT. anends. V, XIV.

2. Monaghan, Of "Liberty" and "Property," 62 CoRnell L. Rev. 405,409 (1977).

3. 408 U.S. 564 (1972).

4. 408 U.S. 593 (1972). 
sistency. ${ }^{5}$ Nevertheless, academics have been uniformly critical of the Court's approach. This Article undertakes the task of defending and explaining the Roth-Perry doctrine and answering its critics. I beheve that the Roth-Perry approach is the right one-but even if it is not, it is important that the reasons for its adoption and durability be understood.

Part I of the Article discusses the background to Roth and Perry, the cases themselves, and the possible alternatives the Court might have adopted. Part II defends the Roth-Perry doctrine. It argues that the doctrine maintams the proper role of administrative discretion in disburseinent of government benefits by separating substance, which is properly the states' province, from procedure, which has as final arbiter the Supreme Court. Furthernnore, the Roth-Perry rule is consistent with the historical understanding of "property." Finally, Part III responds to the scholarly critics of Roth and Perry.

\section{I \\ BACKGROUND}

\section{A. The Emergence of Procedural Limitations on Denial of Government Benefits}

Before World War II, the provisions of the due process clauses imposed few restraints-either substantive or procedural-upon the government in its dispensation of benefits. Quite simply, government benefits were not viewed as fourteenth amendinent "property." Justice Holmes' oft-quoted epigrain captured the order of the day: "The petitioner may have a constitutional right to talk politics, but he has no constitutional right to be a policeman." The great freedoin accorded governments acting in what might loosely be referred to as their proprietary role ${ }^{7}$ seems adequately explained by two commonplace observa-

5. See, e.g., Vitek v. Jones, 445 U.S. 480, 488-91 (1980), and cases cited therein. The only exception is New Motor Vehicle Bd. v. Orrin W. Fox Co., 439 U.S. 96 (1978). This consistency is, I beheve, unequaled in any other area. Cf. Cox, The Supreme Court, 1979 Term-Foreword: Freedom of Expression in the Burger Court, 94 HARv. L. Rev. 1, 24-26 (1980) (discussing the Court's mconsistency in first amendment cases).

6. McAuhffe v. Mayor of New Bedford, 155 Mass. 216, 220, 29 N.E. 517, 517 (1892). Justice Holmes' epigram captures so well the mood of this period, that no discussion of "unconstitutional conditions," no matter how brief, is complete without it. Professor Robert O'Neil described it as "[t]he most durable statement of the 'privilege' concept, if not the soundest." O'Neil, Unconstitutional Conditions: Welfare Benefits with Strings Attached, 54 CALIF. L. REv. 443, 445 n.11 (1966).

7. Professor Van Alstyne puts the matter more precisely: "[A government acts in a proprietary capacity] when the state acts as owner, proprietor, employer, contractor, or otherwise in a manner more characteristic of the private sector than of government." Van Alstyne, Cracks in "The New Property": Adjudicative Due Process in the Administrative State, 62 CORNell L. REv. 445, 448 (1977). As an extreme statement of this position, he quotes the following passage from 
tions. First, when the Supreme Court construed the fourteenth amendment's due process guarantee, it was considerably more concerned with protecting traditional property rights than with protectimg the dignitary and political rights which so occupy the present Court's attention. Second, government benefits were much less important then than they are now. These differences made it possible to live with doctrines that sharply distimguished between government regulation of private property rights, which was closely supervised by the Court, and government disbursement of benefits, which was not. ${ }^{8}$

The most obvious consequence of the right-privilege distinction was the extensive freedom it allowed governments in their daily activities. Subject only to the then-minimal requirements of the equal protection clause, ${ }^{9}$ governments could regulate, eniploy, contract, and provide services using almost any criteria-and almost any (or almost no) procedures. As early as the decision in Pennoyer $v$. Neff, ${ }^{10}$ the due process guarantee was viewed as providing procedural protection of traditional property; due process protection of an expected government benefit, however, was not even within the pale of consideration.

The earhest changes in this area took the form of the Court's recognition that governments are bound by the substantive requirements of the Constitution, even in their proprietary roles. ${ }^{11}$ In a series of cases beginning shortly after World War II, ${ }^{12}$ the Court established that even ephemeral expectations of government benefits could not be denied on a substantive basis that seriously interfered with conduct protected by provisions of the Constitution. These decisions, however, were aimed at protecting substantive constitutional rights (freedom of expression, free exercise of rehion, and the fifth amendinent right not to incriminate oneself), not at protecting the imdividual's right to the

the Tennessee Supreme Court's opiniou affirming the conviction of Scopes in the famous "monkey trial": "In dealing with its own einployees engaged upon its own work, the State is not hompered by the limitations of . . . the Fourteenth Amendment to the Constitution of the United States." Id. at 447-48 (quoting Scopes v. State, 154 Tenn. 105, 112, 289 S.W. 363, 365 (1927) (emphasis added by Van Alstyne)).

8. See Reich, The New Property, 73 YALE L.J. 733, 742 (1964); Van Alstyne, The Demise of the Right-Privilege Doctrine in Constitutional Law, 81 HARv. L. REv. 1439, 1444-47 (1968).

9. See, e.g., Railway Express Agency v. New York, 336 U.S. 106 (1949).

10. 95 U.S. 714 (1878).

11. Part of this change encompassed the Court's rejection of the right-privilege distinction. Leading and informative discussions of that rejection include: French, Unconstitutional Conditions: An Analysis, 50 GEo. L.J. 234 (1961); Linde, Justice Douglas on Freedom in the Welfare State: Constitutional Rights in the Public Sector, 39 WASH. L. REV. 4 (1964); O'Neil, supra note 6; Van Alstyne, supra note 8; Note, Unconstitutional Conditions, 73 HARV. L. REv. 1595 (1960).

12. Justice Stewart, writing for the Court in Perry v. Simdermann, 408 U.S. 593, 597 (1972), apparently dates the development to United Public Workers v. Mitchell, 330 U.S. 75, 100 (1947). See also Frost \& Frost Trucking Co. v. Railroad Comm'n, 271 U.S. 583 (1926). 
benefit itself. ${ }^{13}$

By 1970 , the disbursement of governmental benefits was subject to considerable judicial limitation, although the restrictions were still related almost exclusively to the protection of substantive constitutional rights. These new limitations gradually led to acquiescence in judicial supervision of the daily activities of government; it was no longer quite so acceptable to justify nonsupervision by arguing that the government's right to discontinue benefit programs altogether carried with it the right to operate the program in any fashion it considered appropriate. ${ }^{14}$ In turn, the gradual development of substantive due process limitations inevitably forced the issue of whether or not procedural due process limitations were also applicable to the denial of government benefits. Indeed, some of the cases enforcing substantive limitations actually imposed procedural requirements as a ineans of ensuring that substantive constitutional rights would not be impaired. ${ }^{15}$

A simultaneous and enormous increase in the variety and importance of government benefits added substantial impetus toward extending procedural due process requirements to cover the disbursement of these benefits. While the role of government benefits in the lives of Americans had been increasing gradually since the beginning of the New Deal, President Johnson's Great Society introduced an unprecedented expansion of government programs. ${ }^{16}$

Finally, both the legal hiterature and popular discussion increasingly promoted the view that receiving benefits was one of the rights of the needy, not simply a gratuity dispensed by a charitable government. The legal hterature was particularly insistent in its claim that receipt of government largess was entitled to judicial protection. Expectations of government benefits were "the new property," and preservation of individual freedom required, above all else, that the new property be provided systematic substantive and procedural protection against government arbitrariness, caprice, and worse. ${ }^{17}$

13. See, e.g., Gardner v. Broderick, 392 U.S. 273 (1968) (self-incrimination); Sherbert v. Verner, 374 U.S. 398 (1963) (free exercise of religion); Speiser v. Randall, 357 U.S. 513 (1958) (freedom of expression).

14. For an example of such a justification, see Hale, Unconstitutional Conditions and Constitutional Rights, 35 Colum. L. Rev. 321, 321-22 (1935): "If I have no ground for complaint at being denied a privilege absolutely, it is difficult to see how 1 acquire such a ground merely because the state, instead of denying me a privilege outright, offers me an alternative, however harsh."

15. See, e.g., Freedman v. Maryland, 380 U.S. 51 (1965).

16. See generally S. Levitan, The Great Society's PoOR Law 3-47 (1969). The key legislation was the Economic Opportunity Act of 1964 , which included a number of special programs. Other pertinent legislation imcluded the Housing Acts of 1965 and 1968, the Medicare bill of 1965 , the Eleinentary and Secondary Education Act of 1965, and the Demonstration Cities and Metropolitan Development Act of 1966.

17. The leading article in this area was Reich, supra note 8. Others included Law of the 


\section{B. Cases Developing Supreme Court Doctrine}

\section{Goldberg v. Kelly}

The Supreme Court made its first serious effort to deal with the "new property" in Goldberg v. Kelly. ${ }^{18}$ Plaintiffs, welfare recipieits in New York City, sued to establish that New York's welfare termination procedures were constitutionally inadequate under the due process clause. The case did not in fact present the issue of whether welfare benefits were within the "life, liberty or property" protected by the due process clauses, because defendants conceded that "the protections of the due process clause apply." 19 Nevertlieless, in his opinion for the Court, Justice Brennan addressed the issue. Drawing heavily on the "new property" literature, ${ }^{20}$ Justice Brennan suggested that whetler the right to continue receiving a government benefit was within the protcction of the due process clause turned upon the iniportance of the benefit to the mdividual - that is, the extent to which loss of the benefit would be "grievous." 21 Welfare, Justice Brennan reasoned, is among the inost important benefits government has to offer. Goldberg was widely viewed as an important first step toward the adoption of a rule that government benefits-at least important ones-are fourteentli amendment property. ${ }^{22}$

Poor, 54 CALIF. L. Rev. 319 (1966). But see Handler, Controlling Official Behavior in Welfare Administration, 54 CALIF. L. REv. 479 (1966) (criticizing Reich's approach).

18. 397 U.S. 254 (1970).

19. The district court stated the following:

Defendants do not deny plaintiffs' general propositions that the terminations here under attack amount to "state action" and that the protections of the due process clause apply. Nor do defendants attempt to argue that welfare benefits are a "privilege," rather than a right, and that therefore they may fix the procedures of termination as they sce fit.

Kelly v. Wyman, 294 F. Supp. 893, 898 (S.D.N.Y. 1968).

20. Justice Brennan cited Reich's New Property article, supra note 8, and quoted extensively from Reich, Individual Rights and Social Welfare: The Emerging Legal Issues, 74 YALE L.J. 1245 (1965) [heremafter cited as Individual Rights]. See Goldberg v. Kelly, 397 U.S. 254, 262 n.8 (1970).

21. 397 U.S. at 263. The full sentence is as follows:

The extent to which procedural due process inust be afforded the recipient is infiuenced by the extent to which he may be 'condemned to suffer grievous loss,' Joint Anti-Fascist Refugee Comm. v. McGrath, 341 U.S. 123, 168 (1951) (Frankfurter, J., concurring), and depends upon whether the recipient's interest in avoiding that loss outweighs the governmental interest in summary adjudication.

Read hiterally, the opinion appears to relate "grievous loss" not to the question of whether the due process clause applies, but to the question of "the extent to which procedural due process must be afforded" to the recipient. 397 U.S. at 262-63. This would appear to be addressed to which particular protections ought to be provided - "how much" rather than "whether." But subsequent opinions have read Goldberg for the proposition that the availability vel non of due process protection turns on "grievons loss," and in context this seems a fair if not entirely literal reading of the sentence in question.

22. See Escalera v. New York City Hous. Auth., 425 F.2d 853, 861-63 (2d Cir. 1970); Sostre v. Rockefeller, 312 F. Supp. 863, $871-73$ (S.D.N.Y. 1970); Davis v. Toledo Metropolitan Hous. Auth., 311 F. Supp. 795, 796-97 (N.D. Ohio 1970). Professor O'Neil, in contrast, perceived "a 


\section{Roth and Perry}

Two years after Goldberg, in Board of Regents v. Roth ${ }^{23}$ and Perry v. Sindermann, ${ }^{24}$ the Court rejected the implication in the Goldberg dictum that whether or not a benefit was fourteenth amendinent "property" turned on the importance of the benefit. The method of analysis the Court adopted in these two cases has proven far inore durable than the Goldberg approach.

In Roth, the plaimtiff was a Wisconsin state university teacher whose one-year contract had not been renewed. He challenged the nonrenewal partly on the ground that the university's failure to provide a statement of reasons and a hearing violated his right to procedural due process. ${ }^{25}$ The district court (per Judge James Doyle) granted Roth's summary judgment motion on the basis of his procedural due process claim; the Seventh Circuit affirmed. The Supreine Court reversed the grant of summary judgment.

Roth was untenured. The relevant Wisconsm statute provided that all state university teachers would be on probation until they had served contmuously for four years. The Supreme Court held that the probationary nature of Roth's position meant that Roth did not have a fourteenth amendment property imterest in his job. The Court did not look to the "importance" of the benefit; if it had, it would likely have decided the other way, since employinent is surely important. Rather, the Court found its answer by looking to Wisconsin law. Because Roth was hired for a year only, without any promise that his einployment would continue beyond that period, Roth's expectation of reemployment was not "property" and was therefore not within the protection of the due process clause. Accordingly, Roth was not entitled to any procedural protections over and above those-if any-provided by state law. Roth's substantive interest was "created and defined by the terms of his appointment,"26 and the Court looked to those state-law terms to determine whether or not Roth's expectation was "property."27

The plamtiff in Perry, Robert Sinderinann, was also a state college teacher whose contract had not been renewed; like Roth, he received

lurking implication" that "the Court has begun compiling a rank order or priority list of government benefits." O'Neil, Of Justice Delayed and Justice Denied: The Welfare Prior Hearing Cases, 1970 SuP. Cr. Rev. 161, 180-81.

23. 408 U.S. 564 (1972).

24. 408 U.S. 593 (1972).

25. Roth also alleged that his termination was invalid because it transgressed a substantive himitation. He charged that he had been fired because of protected first amendment activity. This charge, however, was not before the Suprene Court; the district court had stayed proceedings on that issue pending Supreme Court review of the summary judgment. 408 U.S. at 574.

26. Id. at 578 .

27. Id. at 577. 
no notice, hearing, or statement of reasons. Sindermann had been employed by the Texas state college system for ten years, but always under one-year contracts. $\mathrm{He}$, too, challenged his nonrenewal partly on procedural due process grounds. The district court entered summary judgment against him, the Fifth Circuit reversed the trial court, and the Supreme Court affirned the Fifth Circuit.

Documents issued by his employer suggested that Sindermann, though not tenured, was in fact entitled by state law to continuing reemployment absent cause for nonrenewal; these documents, however, did not provide procedural protections against nonrenewal. ${ }^{28}$ The Supreme Court held that whether or not Sindermann's expectation of reemployinent was due process "property" would turn upon whether or not the substantive law of Texas gave Sindermann a "contractual or other claim to job tenure."29 If Sindermann's interest were "property" under this definition, he would be entitled to certain procedural protections under the fourteenth amendment, whether or not state law provided for such procedures. ${ }^{30}$

What are the principles that emerge from Roth and Perry? First, taken together, the decisions delineate federal and state roles in the creation and protection of property rights. The states are given great latitude to choose the substantive rights they want to establish. Once a state creates an expectation which rises to the level of fourteenth amendment "property," however, the federal courts, and not the states themselves, will have ultimate control over the nature and sufficiency of the procedures provided to protect that expectation.

Second, both Roth and Perry reject the Goldberg "importance" test. $^{31}$ They do not clearly indicate what will replace it-what kind of

28. One of these documents was the college's official Faculty Guide, which included the following statement:

Teacher Tenure: Odessa College has no tenure system. The Administration of the Col-

lege wishes the faculty member to feel that he has permanent tenure as long as his teach-

ing services are satisfactory and as long as he displays a cooperative attitude toward his

co-workers and his superiors, and as long as he is happy in his work.

Perry v. Simdermann, 408 U.S. 593, 600 (1972); see also id. at 600 n.6 (noting that the Texas college and umversity system guidelines contamed similar provisions for an expectation of employment).

29. Id. at 602 n.7.

30. Id at $602-03$.

31. The opinions do not expressly overrule Goldberg's dictum. But in his discussion of Goldberg in Roth, Justice Stewart (writing for the Court) performcd a remarkable job of "plastic surgery," Shuttlesworth v. Birmingham, 394 U.S. 147, 153 (1969) (Stewart, J.), upon that opinion's holding. Gone entirely is Goldberg's consideration (in three places) of the importance of the government benefit; instead, the result in Goldberg is rationalized by the fact that "the welfare recipients' 'property' interest in welfare payments was created and defined by statutory terms . . .." Roth, 408 U.S. at 578. See also id. at 576 ("IA] person rcceiving welfare benefits under statutory and administrative standards defining eligibility for thein has an interest in contmued rcceipt of those benefits . . . ."); id. at 577 ("[T]he welfare recipients in Goldberg $v$. Kelly had a claim of entitlement to welfare payments that was grounded in the statute defining eligibility for them."). 
state-law-based expectancy will be considered fourteenth amendment "property." Rather, Justice Stewart's opinions for the Court proceed in a "magisterial" style. ${ }^{32}$ Unlike more typically argumentative modern opinions, they do not articulate either the policies which justify the dichotomy adopted in Perry and Roth or the test that will be used to determine whether or not a particular expectation is fourteenth amendment "property." All that is really clear in Roth and Perry is that the Court will leave to the states the complex decisions concerning the scope and nature of benefits they may choose to disburse, but will reserve for itself the determination of the procedures that must be provided once a state has created a protected expectation.

With the benefit of hindsight, we can now see the kind of test the Court meant to impose in Roth and Perry. It turns upon the kind of decision that will govern the continued receipt of the government benefit. If, as in Roth, the legislation or regulations granting the benefit condition its receipt upon the discretionary decision of an administrator, the expectation of the benefit is not "property." Conversely, if, as was alleged in Perry, continuing ehgibility for the benefit turns, by state law, upon the existence or nonexistence of particular facts, the expectation of the benefit is fourteenth amendment "property."

\section{Arnett v. Kennedy}

The Supreme Court has adhered with remarkable consistency to the Roth-Perry doctrine. In Arnett $v$. Kennedy, ${ }^{33}$ however, a plurality of the Court, composed of Chief Justice Burger and Justices Stewart and Rehnquist, proposed a different analysis.

Wayne Kennedy, the plaintiff, was a government employee fired for making public statements to the effect that his immediate supervisor had attempted to give a bribe. ${ }^{34}$ Kennedy sued, claimmg that the pro-

This "plastic surgery" cannot hide the fact that the Court was consciously rejecting Goldberg when it said that "to determine whether due process requirements apply in the first place, we must look not to the 'weight' but to the nature of the interests at stake." Id. at 570-71 (einphasis in the original). It is nonetheless true that Goldberg's holding may stand consistent with Roth and Perry: New York had set up statutory eligibility criteria for welfare benefits and therefore had eliminated most unreviewable discrction.

32. Cf. Cardozo, Law and Lilerature, 39 Colum. L. REv. 120, 123, 52 HARV. L. Rev. 472, 475, 48 YALE L. J. 490, 493 (1939), who, after listing various styles of opinion writing, described the magisterial style in this way:

I place first in order, for it is first in dignity and power, the type inagisterial or imperative. It eschews ornament. It is meager in illustration and analogy. If it argues, it does so with the downward rush and overwhelming conviction of the syllogism, seldom with tentative gropings towards the inductive apprehension of a truth imperfectly discerued. We liear the voice of the law speaking by its consecrated ininisters with the calmness and assurance that are born of a sense of mastery and power. Thus Marsliall seemed to judge, and a hush falls upon us even now as we listen to his words.

33. 416 U.S. 134 (1974).

34. Kennedy's statement was to the effect that his supervisor "liad attempted to bribe Mr. 
cedures attending his termination had been constitutionally insuffcient. Under the apphicable civil service regulations, Kennedy's pretermination hearing rights were limited to very informal proceedings before his supervisor, ${ }^{35}$ who in this case was the very person whoin Kennedy had allegedly defamed. By contrast, the regulations provided for very elaborate post-termination hearings before an impartial exaininer, as well as the right to reinstatement with backpay should the employee prevail.

Kennedy attacked the statutory procedures for their failure to provide a pretermination hearing before an impartial hearing officer. Although the Court was unable to agree on a majority opimion, five of its nembers concurred in the judgment rejectimg his attack. Justice Rehnquist, joined in his plurality opinion by the Chief Justice and Justice Stewart, agreed with all the other Justices that Kennedy's interest in his federal classified civil service job was due process "property." 36 Nonetheless, he would have limited Kennedy to the procedural safeguards provided by the statutes that created the substantive terms of his einployment. Where, as here, it appeared that Congress had paid close attention to the procedures that would be available when enacting the legislation that created the job tenure, the substantive riglit, Justice Rehnquist argued, could not be divorced from the procedures provided for its enforcement: "[W]here tlie grant of a substantive riglit is inextricably intertwined with the limitations on the procedures which are to be employed in determining that right, a hitigant in the position of appellee must take the bitter with the sweet." 37

The other six Justices rejected Justice Rehnquist's analysis. In their view, Roth and Perry required that if the benefit in question was "property," the Court inust independently determine the adequacy of the procedures Congress provided. Justices Blackmun and Powell concluded, after such an independent review, that the limited preterninination procedures provided by the statute were in fact constitutionally adequate, in view of the extensive post-termination procedures avail-

James White Eagle Stewart by offering him a $\$ 100,000$ grant of OEO funds if he would sign a statement 'against [Kennedy]. . . . " Id. at 196-97 (White, J., concurring and dissenting).

35. Id. The government provided the employee with the right to 30 days written "notice of proposed adverse action," including "any and all reasons, specifically and in detail, for the proposed action." He was then entitled to a reasonable time to submit a written answer, as well as the right to make a personal appearance before an official who had authority either to make the final decision or to recommend what final decision should be made-all prior to the making of the final decision. These requirements were in addition to extensive post-termination evidentiary hearings.

36. Id. at 151-52 (Rehnquist, J., joined by Burger, C.J., and Stewart, J.). The same point was made by each of the other Justices. Id. at 164-67 (Powell, J., concurring im part, joined by Blackmun, J.); id. at 171, 184-86 (White, J., concurring and dissenting); id. at 206, 207-11 (Marshall, J., dissenting, joined by Douglas and Brennan, JJ.).

37. Id. at $153-54$ (plurality). 
able. Accordingly, they voted with the plurality to uphold the statute, though theirs was a markedly different analysis. The other four Justices concluded that the procedures were in soine regards constitutionally inadequate, and on that basis would have voted to uphold Kennedy's attack.

The plurality's analysis is patently inconsistent with the RothPerry reasoning. ${ }^{38}$ It did not reject Perry and Roth outright; rather, the opinion was carefully limited to situations in which the state or Congress had, in the process of defining the scope of the substantive right, given simultaneous and careful consideration to the procedures it wanted to provide. ${ }^{39}$ Nonetheless, even if such a limitation were ultimately feasible and capable of application, ${ }^{40}$ giving legislatures the power to limit procedural rights is a pro tanto retraction of the plenary judicial power over procedure that the Court seemed to contemplate in Roth and Perry.

This history, from Goldberg to Roth-Perry to Arnett, traces the Supreme Court's progression from having no articulated doctrine on the meaning of property under the fourteenth amendment to deciding cases representimg three separate positions. Three Justices (Brennan, Marshall and Douglas) would follow the Goldberg reasoning and accord procedural due process protection to any "important" expectation of government benefit, whether or not it turned upon the discretion of an administrator. Three other Justices (White, Blackmun and Powell) would follow Roth-Perry and accord procedural due process protection to expectations of governmental benefits only (and always) when the expectation was grounded in state law and conditional only upon the existence of historical facts-not upon the discretion of an administrator. Finally, three Justices (Chief Justice Burger and Justices Stewart and Rehnquist) would adopt the Arnett plurality approach, and accord procedural due process protection only to nondiscretionary benefits, with the additional limitation that any protective procedures provided by the legislature creating the interest would always be constitutionally sufficient. Roth and Perry, taken together, define the middle ground of these three possible positions. The Court has consistently looked not to

38. This is true even though Justice Stewart, the author of Perry and Roth, joined Justice Rehnquist's plurality opinion.

39. See id. at 152 ("where the focus of the legislation was thus strongly on the procedural mechanism . . ."); id. at 153-54 ("where the grant of a substantive right is inextricably intertwined with the limitatious on the procedures ..."). This point is made in Comment, No Hearing Required Prior to Dismissal for Cause of Nonprobationary Federal Employee, 59 MINN. L. REv, 421, 427-28 (1974).

40. Cf. Comment, supra note 39 , at 427 ("Unfortunately the plurality opinion failed to offer any clear criteria for determining how the strength of the focus of legislative intent is to be measured.") 
the reasoning of Goldberg or Arnett, but to the Roth-Perry analysis. The response has been criticism from both sides: those who would take a Goldberg-like approach condenun Roth for not providing enough procedural protection, while critics taking the Arnett position think that the Perry Court went too far in reserving procedural determinations to the courts. The next Part of this Article will address these criticisms by making a case for the Roth-Perry approach.

II

\section{AdMinistrative DisCRETION AND the JUdicial Process-The CASE FOR THE Roth-PERRY DOCTRINE}

The above-nentioned criticisms present two questions. The first question is whether Roth was wrong because it did not go far enough to ensure that recipients of government benefits have sufficient procedural protections. My answer is that Roth was right: many questions regarding government benefits are properly cominitted to administrative discretion, which by its very nature is unreviewable through judicial procedure. Moreover, the definition of "property" that Roth uses is consistent with a well-established meaning of the word. The second question is whether Perry was wrong to reserve the ultimate determimation of minimal procedural protection to the courts, where the benefit in question does not turn on the discretion of an administrator. Perry too, was correct: the Court was simply treating "the new property" as it had always treated traditional property for the purposes of the Constitution's due process guarantee.

This Part presents these answers in detail. Although Roth and Perry should be seen as a single doctrime, I have found it convenient to defend them separately. I begin by answering the criticisin that the Court did not go far enough im Roth.

\section{A. In Defense of Roth: A Response to Goldberg}

I defend Roth on two bases. The first is a utilitarian defense based on what would have happened had the Court decided the case differently. If the Court had imcluded Roth-type expectations within the definition of fourteenth amendinent property, the immediate result would have been full judicial review of administrative decisions, and the ultimate end would have been the effective destruction of administrative discretion. My second defense is traditional, perhaps textual. The Court's dichotomy between expectations that turn upon factual criteria predefined by the state ("property") and expectations that turn upon the discretion of an administrator (not "property") conforms closely to the usual use of the term "property." The first of these defenses is, in 
my view, the more important; I will begin this Section with it, and will devote considerably inore attention to it than to the second argument.

\section{The Functional Defense: Preservation of Administrative Discretion}

The functional defense is simply stated: requiring even a statement of reasons for Roth's interest would inevitably have meant the curtailment of administrative discretion and a substantial loss of administrators' freedom to rely upon their intuition, their impressions, and their underlying goals, aims, and values when inaking discretionary decisions.

Before showing that this result is inevitable, I should state the assumption upon which I proceed. The assumption is that there are two distimct types of decisional problems, one of which is well-suited to adversarial decisionmaking and one which is not. The latter type of problem is not amenable to the strictly rational, "principled" analysis we associate with the adversary process and with judicial determinations. Professor Lon Fuller calls these problems "polycentric" and argues that they cannot be resolved by adjudication because "[t]here is and can be no single solution or issue toward which the affected party inay direct his proofs and arguinents." 41 Professor Fuller recommended that inanagerial authority-administrative discretion--should be used, instead of adjudication, to solve this type of problem. This distinction between between nonadjudicable administrative problems and discrete litigable problems underlies iny analysis of Roth.

Assuming that the distinction between the two types of decisions exists, which type was involved in Roth? Termination of the contracts for untenured Wisconsin college teachers' was cominitted by state law to the sound discretion of an administrator. Nonrenewal decisions, then, were of the nonadjudicable type. Does this inean that imposing procedural requirements in Roth would have led inexorably to the substantively serious result-namely, loss of administrative discretionpredicted at the beginning of this Section? In other words, would giving David Roth a simple statement of reasons for his nonrenewal and a himited opportunity to respond swallow up the political science cliairman's discretion? ${ }^{42}$ At first glance, the suggestion seems preposterous.

41. Fuller, Adjudication and the Rule of Law, 1960 AM. SOC'Y INT'L L. Proc. 1, 4. See also Fuller, Collective Bargaining and the Arbitrator, 1963 WIs. L. REv. 3; Henderson, Judicial Review of Manufacturers' Conscious Design Choices: The Limits of Adjudication, 73 Colum. L. REv. 1531, 1534-39 (1973). The term appears to have originated in M. POLANYI, The Logic of LiberTy: REFLECTIONS 170 (1951).

42. In fact, it appears that Roth's chairman was in favor of retaining him, and that the decision not to renew his contract came from above. The five members of the political science department who were servor to Roth initially voted unanimously to "highly recommend" Roth's reappointment, and the chairman submitted a strongly favorable recommendation. Dean Arthur 
A simple statement of reasons seems such an innocuous and unburdensome requirement that one would suppose only those who had something to hide would oppose it. ${ }^{43}$

My response is that the first glance does not tell all. First, a statement of reasons lets the camel's nose in the tent: once reasons are required, judicial enforcement of the requirement will be necessary, and from that, full judicialization of the decision will surely follow. Second, once a decision has been judicialized, only the hardiest administrators will make an adverse decision if they do not have the type of evidence needed for a judicial defense of that decision. Such evidence will reflect certam kinds of discrete, factual criteria. Consequently, the existence of the specific hard data will become the determining factor in their decisionmaking. Administrators' freedom to combine somewhat less convmcing evidence with their mtuition will be lost, and their decisions will turn on substantive criteria other than those intended by the origmal lawmaker. These two steps im the defense of my thesis are sufficiently important to deserve separate treatment; I devote the next two Sections to them.

\section{a. The Costs of a Statement of Reasons}

In his Roth dissent, Justice Marshall argued that a reasons requirement would not be burdensome. ${ }^{44}$ His notion is that such a reasons requirement would provide a convenient conipromise between the full adversary proceeding required by Goldberg and the lawlessness permitted by Roth.

The flaw in Justice Marshall's argunent is that it focuses on the minimal administrative burdens imvolved im actually giving the reasons. Recent experience mdicates that even when admimistrators must make large nunibers of decisions, they can give simple statements of

Darken then met individually with four of the five; he did not meet with the chairman, who happened to be the only untenured one of the five. The members of the department then reconvened, apparently over the chairman's objection, and voted again on Roth. This timc the vote was 2-1 against reappointment, with two abstentions. Dean Darken then forwarded his recommendation to the President, in a inemorandum which frankly concluded: "I am happy, therefore, to be able to inake a recommendation that supports the 2-1 vote for nonretention submitted by the Policital Science Department Tenure Committee." Petition for Ccrtiorari Appendix at 125-31, Roth; Brief for Respondent at 3-6, Roth.

Throughout this Article I will use the pohitical science chairman as a mctaphor for an administrator with important administrative discretion. In fact, the discretion exercised at the school and campus levels by deans, chancellors, and the hike is at least as important to the excellence of a university and its departments as is the discretion exercised by the departmental chairman. The issues before the chairman, however, are easier to visuahize and to discuss, and for that reason I will continue to refer to the Roth decision as if it wcre made by David Roth's chairman.

43. See Roth, 408 U.S. at 591 (Marshall, J., dissenting).

44. Id. 
reasons expeditiously, without incurring any real burden. ${ }^{45}$ Thus, requiring a statement of reasons in Roth would have imposed only a minuscule additional administrative burden. ${ }^{46}$ The real burden accrues not from the task itself, however, but from the fact that its performance is judicially commanded and judicially enforced. Justice Marshall overlooked the effects of that command; judicially mandating a statement of reasons means that there is no stopping at the halfway point. Without judicial enforcement, the reasons requirement would so frequently produce a hollow, formal statement that the drive to judicial supervision would be irrestible. Once the courts require a statement of reasons, they will have to enforce and supervise that requirement.

I can see two reasons why unreviewable reasons requirements would be useless. First, if there were no judicial review, even administrators without malice or evil motives might act in such a way as to empty a "reasons" requirement of any significance. For example, administrators could state their "ultimate" reasons without explaining their evidentiary bases. Thus, Roth's departmental chairman could simply have stated that Roth was msubordmate, a poor teaclier, uninformed in his field, uninspiring or irresponsible in the conduct of his classes or the grading of his papers, and so on. If the chairman had doubts about reappointment, he must have had genuine concerns about Roth's performance in at least some of these or similar areas, and could easily have stated them witl a clear conscience. If the factual basis for the statement of reasons were absolutely unreviewable, even if Roth and the chairman both knew that otlier, inore serious, problems were involved and that the stated reasons were not the entire or even the mam explanation of the result, Roth would be powerless to do anything about it. The statement given would be a hollow formahty, but in the absence of serious judicial review would nonetheless satisfy the requirement of a "statement of reasons."

There is a second reason why a "reasons" requirement not judicially enforceable would soon become meaningless: administrators could give their reasons in euphemistic generahties, knowing that the bases for the decision could not be challenged. For example, the cliairinan might simply have stated that, in his judgment, Roth did not have as great a potential for scholarly success as others he might hope to hire. An administrator who could satisfy the reasons requirement by

45. Professor Davis reported that, at his suggestion, the Immigration and Naturalization Service adopted the policy of giving a brief statement of the reason for denying a written application. Although this required statements on approximately 35,000 applications per year, the INS was able to implement the policy with no increase in the size of the staff necessary to handle the applications. K. Davis, Administrative Law Treatise 562 (Supp. 1970).

46. For this reason, a voluntary (and therefore non-judicially enforced) statement of reasons is not only not burdensome, but in fact highly desirable. 
giving such a statement would not give more. Such a toothless requirement would not have helped Roth, and would prove similarly unhelpful to all mdividuals adversely affected by admmistrators' decisions.

Without some sort of judicial enforcement, then, a "reasons" requirement would soon degenerate into a hollow formality. ${ }^{47}$ And that's the rub. The judicial review necessary to keep this from happenimg turns out to be quite substantial. An example of the type of judicial review which would be necessary to enforce a reasons requirement is provided by two consolidated cases decided by United States District Judge James Doyle four days after he decided Roth. The cases, Gouge v. Joint School District No. 1 and Klein v. Joint School District No. $1,^{48}$ involved two untenured but long-term ${ }^{49}$ school teachers who had been dismissed by their rural Wisconsin school district. Although the controlling statute required neither a statement of reasons nor a hearing, the district's administrator provided both. ${ }^{50}$ Each teacher met with the school board; at the teachers' request, the district administrator was excluded froin those meetings. After the meetings, the school board voted not to reappoint either teacher. Both brought actions for wrongful termination.

As the trial judge im Roth, Judge Doyle had held that, under the

47. The chief proponent of a reasons requirement, Professor Robert Rabin, agrees that such a requirement would be of little value without substantial judicial review:

If the requirement of a rational explanation is to have meaning it must be based on more than an uuenforceable obligation to supply reasons. Without soine form of judicial review, the individual would remain vulnerable to irrevocable changes in status unsupported by an adequate explanation simce the reasons requirement could be ignored with impunity.

Rabin, Job Security and Due Process: Monitoring Administrative Discretion Through a Reasons Requirement, 44 U. CHI. L. Rev. 60, 84 (1976).

Other writers have suggested more ephemeral purposes. Professor Pincoffs, for example, enphasizes that a statement of reasous for an employee's dismissal will show that the employer is mterested in helping the employee improve himself and therefore contribute to the employce's self-respect. Pimcoffs, Due Process, Fraternity, and Kantian Injunction, in 18 Nomos: DuE ProCEss 172 (J. Pennock \& J. Cliapman eds. 1977). See also Michelman, Formal and Associational Aims in Procedural Due Process, in 18 Nomos: Due Process 126, 127 (J. Pennock \& J. Chapman eds. 1977); Kirp, Proceduralism and Bureaucracy: Due Process in the School Setting, 28 STAN. L. Rev. 841, 864-70 (1976); Tribe, Structural Due Process, 10 HARv. C.R.-C.L. L. REv. 269, 310-14 (1975).

48. 310 F. Supp. 984 (W.D. Wis. 1970).

49. Mrs. Saxon Gouge had been employed by the district for six consecutive years at the time it determined not to renew her contract. Id. at 986 . Mrs. Viola Klein had been employed by the district for eightcen years at the time the board took its action. Id. at 987 .

50. Gouge had been a music teacher, the administrator's letter indicatcd that le was recommending ler nonrenewal because her ill lealth had resulted in a decrease of the district's music activities. Klein was a science teacher who was apparently teaching outside her primary area; the administrator's letter to her imdicated that he was recommending her nonrenewal because she had been unenthusiastic about a departmental team teaching program recently introduced in her school, and sle liad not been getting along well with some of lier colleagues. See id. at 986-88. 
Constitution, even untenured teachers must be given a statement of reasons and an opportunity to respond. ${ }^{51}$ The Gouge cases gave him an opportunity to demonstrate what that meant. Judge Doyle held that giving the teachers reasons and a hearing was not enough; the court had to exainine the sufficiency of the protections afforded. He found that each teacher was entitled to trial on three factual issues: first, the actual reasons upon which the board acted in each case; 52 second, whether there was any basis im fact for any of the reasons im either case; ${ }^{53}$ and third, whether the school board misled the plaintiffs as to the number of reasons for nonrenewal and thereby impaired their opportunity to respond effectively. ${ }^{54}$

It must be emphasized that there was no suggestion that the school board had soinehow been improperly niotivated in these cases. Indeed, plaintiffs appear to have conceded that their nonrenewals were not motivated by constitutionally impermissible reasons. What Judge Doyle required is the very minimuni necessary to enforce a reasons requirement. Had the Roth dissenters prevailed, it is what would have been required in every case im which a government entployer terminated the einployinent of an untenured employee. The board would, of course, have to supply the teacher with a statement of reasons and (probably) an opportunity to appear; these, as indicated previously, would not be onerous. If the teacher chose to sue, however, it would be a court's duty to determine whether the constitutional reasons requirement had been coinphed with. In order to do that, a court would have to decide at least four issues:

1. Whether the reasons stated in the board's notice to the teachers satisfied a federal judge's notion of an acceptable basis for terminating an untenured teacher; ${ }^{55}$

2. Whether the reasons stated in the notice were the reasons actually acted upon by the board;

3. Whether the reasons acted upon by the board had a sufficient "basis in fact,"s6 and

51. 310 F. Supp. 972, 979-80, 983 (W.D. Wis. 1970), affd, 446 F.2d 806 (7th Cir. 1971), rev'd, 408 U.S. 564 (1972).

52. Gouge, 310 F. Supp. at 992.

53. $I d$.

54. Id.

55. Judge Doyle specifically held that the reasons stated in Johnson's letters were constitutionally acceptable and sufficient to permit the school board to terminate each of the plaintiffs. Id. at 991 .

56. Professor Rabin would not permit any judicial review of the statement's factual conclusions. He would substitute for this a requirement that the statement's factual findings be highly detailed and specific, on the theory that such statements will be self-pohicing, because administrators will be reluctant to inake very specific findings that they know to be "untrue." Rabin, supra note 47 , at 84-86. There are two fatal defects in his theory. First, it reflects a conception of black 
4. Whether the members of the board did or said anything at the hearing that im any way misled the teachers or interfered with their opportunity to respond to every concern notivating their decision.

Some further matters would have to be brought to the attention of a school board brave enough to consider terminating an untenured teacher. If the teacher seeks damages, the second, third, and fourth issues would be triable to a jury. Should the board prevail at the trial level, the teacher would be entitled to at least one appeal as a matter of right. Furthernore, if the board guessed wrong as to any element of the procedures ultimately found to have been required or made an adverse factual deterinination as to any material element of the procedures actually provided, the school district would face the possibility of a very substantial judgment agamst it. Fmally, win, lose, or draw, the board would be faced not only with the disruption and anxieties present in every lawsuit, but also witl the substantial financial costs of supporting wliat lias become very expensive litigation. All this, it inust be

and white "truth" that is inconsistent with the real world. In fact, an employer who feels he should fire an employee will have no trouble reeling off, in perfect good faith, a dozen "half true" or honestly imagimed factual incidents to support his conclusion. Without judicial review of the factual basis for the findings, the statement of reasons will be little more than a formalistic but insubstantial procedural hurdle; it will provide real protection only where the employer is highly ambivalent. But cf. Dunlop v. Bachowski, 421 U.S. 560, $572-73$ (1975) (Secretary of Labor required to produce detailed statement of reasons for not commencing a civil action to set aside union election, but factual bases for statement not subject to judicial review).

Second, and inore serious, requiring that the statement be detailed would create a horrendous trap for the unwary employer. Rabin provides, as an exainple of an insufficient statement, the following affidavit taken from the trial court record of Bishop v. Wood, 426 U.S. 341 (1976):

1 had [Bishop] in my office on several oceasions during a six month period prior to his discharge, concerning high speed auto chases outside the city limits, checking business establishments in the city and answering patrol calls.

Bishop did not attend training sessions . . . refused to cooperate with fellow officers and did not take orders froin the officer in cliarge of his duty shift. Officer Bishop was the cause of low morale . . . and a verbal complaint was filed against him by Sergeant

Arrowood. . . .

Rabin, supra note 47 , at 90 . Rabin concludes that "an adequate statement of reasons would have required a more precise and detailed explanation of the Cliief's decision than was provided in his affidavit." Id. at 90 n.99. In particular, Rabin considered the statement fatally defective because it was unsubstantiated and because many of the charges were "highly anbiguous." Id. at 90 . It would follow, therefore, that an employer who fired an employee even for perfectly valid and sufficient reasons would ultimately have to reinstate him with back pay, if the statement of reasons were similarly "incomplete."

The net result of Rabin's view would rival the rigors of nineteenth-century code pleading: a government employer who tennmated an untenured employee would be subject to substantial damages and injunctive relief unless it gave the employee a statement of reasons that was "precise and detailed" (when viewed in retrospect by the trial court), "substantiated" and not "highly ambiguous"-requireinents that rival Poineroy's "dry, naked, actual facts" in their ability to strike well-earned fear in the heart of the litigant. See J. Pomeroy, Code Remedies § 423, at 640 (5th ed. 1929). In short, Rabin's requirennent would make it possible successfully to fire an untenured employee-but only if the employer hired a "special pleader" to do it for her. 
remembered, awaits the board every time it chooses not to renew the contract of an untenured teacher.

It is, of course, possible that Judge Doyle was wrong in concluding that a reasons requirement carried with it the necessity for the type of judicial review he provided in Gouge. I think he was correct. Onitting judicial review of any one of the four histed eleinents would invite even honest and open administrators to avoid the brunt of the requirement. If the substantive bases for the determination were beyond review, the administrators could simply state that they did not like the teacher's necktie. In the Gouge situation, if the board were not compelled, by judicial review, to state its real reasons, it inay be tempted to state only a "safe" reason for dismissal-a reason entirely unrelated to its real motivation. If it did so, a chance to respond would be meaningless, for a response prepared in answer to the stated reason would have no real chance of persuading the board to change its mind. Requiring that the reasons have a basis in fact would also seein to be central. Telling the administrators that they can preclude significant judicial review inerely by "finding" facts that are not true would be a teinptation not only to dishonesty but also to something that might be termed "result-oriented factfinding." Finally, Judge Doyle's fourth requirement, that the board not undo with its oral statements the effect of its written reasons would not frequently be an issue; if it were, the need for judicial consideration would also seem self-evident. In sum, the very judge who, in Roth, would have given up a reasons requirement, showed us, in Gouge, just how much review such a requireinent would have entailed. Reasons requirements cannot be made meaningful save by full judicial review. The next Section shows how costly that review would be.

\section{b. The Costs of Judicial Review}

The increased expense of terminating discretionary government benefits is itself a strong argument against a judicially enforced reasons requirement. Moreover, imposing such a requireinent would entail more than monetary burdens. By refusing to take this path, the Roth Court showed a proper respect for the substantive decisioumaking power of the executive branches: judicializing discretionary administrative decisions would not only increase the costs of defending adverse decisions, but would also change the bases upon which such decisions are made from intuitive and impressionistic to factual and easily documented.

Small-particle physics has developed the Heisenberg uncertainty principle, which shows that it is not possible to measure something without changing it. The Heisenberg uncertainty principle seems as applicable to human behavior as it is to the behavior of subatomic par- 
ticles. An einployer who inust explain his reasons for firing an employee-whose behavior is "measured" by judicial review-acts differently froin one who need not. Imposing a reasons requirement will cause administrators to act in ways they think nore likely to withstand judicial scrutiny. Judicial review will, therefore, lead administrators to base their decisions on those factors most easily documented.

Such a change would be detrimental because it would deemphasize a large nuinber of previously important factors. Suppose, for example, that Roth's department chairman concluded that Roth had not proven as imtellectually challenging in the classroom as he had hoped. This opinion might be based on his observation of classes, or on student comments, or on extrapolation from casual conversations between Roth and himself or between Roth and their mutual colleagues in the department. As I have shown, a statement of reasons requirement would make unacceptable the chairman's unsupported statement that Roth was not intellectually deep as a teacher: the chairman would have to satisfy a court that this was his real reason, that it was a substantively acceptable reason, that it was his only reason, and that it was a reasonable inference from the evidence. Adininistrators facing the prospect of such full judicial review would be reluctant to rely merely on intuition; they would want hard evidence to support their position. Without such evidence, they might make decisions different from the ones they had originally intended. In our hypothetical Roth situation, if the routine student evaluations supported the chairman's evaluation, he would probably act on his imtuition. On the other hand, if Roth had proven popular with the students, the chairman might decide that Roth's dismissal could not easily be explained to a jury. In spite of his intuition, he might choose to retain Roth.

The change in the substantive bases upon which the decision turns, as well as in the result, is apparent. Without a reasons requirement, the decision in our hypothetical turned primarily on the chairman's intuitive evaluation of Roth's intellectual depth. The chairman was free to shape his department by following his inarticulable intuitions; he was free to experiment with his hiring decisions. Once the reasons requirement is imposed, nore easily verifiable - but no more valid-factors, such as student evaluations, become crucial. The chairman's freedoin is reduced. Student reviews and other quantifiable indicators replace the subjective, intuitive, and highly fragile criteria that a department chairman would otherwise use to build the departınent.

Aside from this change in substantive bases, a reasons requirement generates an additional cost. If the chairman would be hesitant to termimate Roth without tangible evidence in support of the decision, not only would the factors he would rely upon be different, but, as a practi- 
cal matter, he simply would not make what might very well be a correct decision. The probationary teacher, who formerly had only a hope that he would fit into the future of the department, now has what ainounts to a right to continue down the tenure track unless the chairman feels confident that he can demonstrate deficiencies in the probationary einployee's teaching or publications. A Supreme Court decision adopting a reasons requirement would have the effect of giving probationary pubhic employees something very much like tenure.

In a recent study of the federal classified civil service, Professor Frug showed that imposing procedural protections upon job termination indeed produces this result. He convincingly tied the virtual absence of incompetency discharges ${ }^{57}$ to the existence of judicial review of the supervisor's decisions to fire classified einployees for incompetence and to the required procedures and findings that come with it. ${ }^{58}$ The heart of Professor Frug's thesis is that evaluation of the competence with which an einployee performs his job is largely subjective, but the judicial-type procedures that now accompany civil service discharge force the supervisor to coinpile an objective "record" of the classified employee's deficiencies before firing him. This record will often have hittle to do with the einployee's general coinpetence. ${ }^{59}$ Furthermore, the very process of compiling the record distorts the environment; not only is it intensely unpleasant for the parties themselves, but it inevitably distracts and upsets other employees in the unit. It is therefore not surprising that the federal employer rarely discharges employees for incompetence, or that federal supervisors can seldom demand competence froin their classified employees. Professor Frug's study bears out both of iny points: imposing procedures has caused a change in the bases for decisions-“"imcoinpetence," essentially a subjective criterion, is in effect no longer a basis for discharge $e^{60}$-and has effectively and drastically himited the number of such decisions made.

57. Professor Frug reports that from 1972 through 1974, between 300 and 500 individuals were separated for "mefficiency" from the federal civil service, out of a total of more than two million such employees. This works out to a rate of $0.02 \%$, or one employee separated per 5,000 employees. Frug, Does the Constitution Prevent the Discharge of Civil Service Employees?, 124 U. PA. L. Rev. 942, $945 \mathrm{n} .13$ (1976). It is simply inconceivable that the percentage of incompetent workers in the federal bureaucracy is so low that a separation rate of $0.02 \%$ even begins to handle the problem. Rather, this low figure is simply the product of the fact that it is virtually impossible to separate a classified civil servant solely for incompetence. See id. at 946 n.16.

58. Id. at 946 (footnote omitted).

59. The question is seldom whether or not the einployee "did it," as every einployee occasionally makes imstakes; the real questions involve how often these mistakes were inade, how serious they were, whether the employee has tried to improve his performance, what level of performance is expected of other employees in the unit, and so on. But "when factinding becomes the focus, the true issues in establishing fairness in einployee evaluations are often lost in the process of resolving largely irrelevant factual disputes." Id. at 1001.

60. Justice White was very careful, in his separate opinion in Arnett, to distinguish between 
I have established the results of imposing a reasons requirement. Are those results necessarily bad? Let us return to the Roth-based hypothetical. Is it wrong that an administrator's decision be made to turn on demonstrable criteria? At first glance, it would seem to be a change for the better. I have two responses. First, intuitive criteria are often just as valid as objective criteria. If the chairman is free to replace a probationary teacher when he feels such a replacement will improve the quality of the department, he will create a department with qualities not refiected by more tangible data. Perhaps the teachers chosen through exercise of the chairman's intuition will turn out to be less popular with students, but inore challenging; perhaps their popularity, though lower at the beginning of their careers, will stand up better over the thirty years or so during which they inay be expected to remain in the department; perhaps they will ultimately inake more lasting contributions to the scholarly literature than Roth would have.

Second, the results I liave described are undesirable because they represent an impermissible incursion upon the power of legislatures to decide the bases upon which exccutive decisions are to be inade. If a legislature has decided that it wants these decisions to be made on the basis of the adininistrator's discretion, a court should not lightly disregard that deterunination. We can be certam that, in Roth, the state of Wisconsin had remitted these decisions to the discretion of the responsible university adininistrators. A "reasons" requirement would have limited the very discretion the legislature found desirable.

If it finds judicial-type procedures desirable, the legislature may of course provide for thein. For exainple, the judicialization of competence determinations in the federal classified civil service, the subject of Frug's study, was a legislative decision. ${ }^{61} \mathrm{Had}$ Roth been decided the other way, legislatures would have lost their powcr to provide for truly probationary eniployinent. The result would have been the iinposition of a constitutionally required judicialization of the discharge process on every government agency in the United States-and a constitutionally required quasi-tenure for every government employee in the United States. The alternative to Roth would have been disastrous in several ways, but by far the worst effect would be the limitation of executive and legislative discretion and the transfer of unprecedented power to the courts.

discharges for misconduct and discharges for pure inefficiency. See Arnett v. Kennedy, 416 U.S. 134, 186 (1974) (White, J., concurring and dissenting).

61. I use the term "legislative" in its broader sense. In fact, Congress took the first step by providing an elaborate appellate procedure for veterans who had been discharged in the Vetcrans Preference Act of 1944. Frug, supra note 57, at 959-60. President Kennedy extended similar protections to all classified employees by Executive Order in 1962. Id. at 960-61. 


\section{c. Roth and Administrative Irrationality}

This Section has demonstrated that the imposition of procedural protections in Roth would have led inexorably to full judicialization, and that such judicialization would ultimately change the substantive bases of administrators' decisions. The reinainder of this Section deals with an objection that is sure to be inade: even if jobs are not property, if courts impose no procedural requireinents to ensure judicial review, administrators will be free to act in completely arbitrary ways. My response is that they will not.

It is standard constitutional rhetoric that the due process and equal protection clauses require government actions to have soine rational relationship to a legitimate end. ${ }^{62}$ And it is true that the Supreine Court does not admit that irrational government action may not run afoul of the Constitution. In reality, however, there are many areas of government activity in which the Court will not test for rationality. I beheve that Roth represented a decision by the court that discretionary administrative action should reinain immune froin automatic rationality review in every case-and that this is not a defect in the decision.

By requiring judicially reviewable reasons for every administrative decision, the Roth dissenters would have held, in Justice Marshall's terms, that "[t]he government may act only fairly and reasonably." 63 This would have imposed a substantive, not a procedural, requirement-it would have controlled the bases upon which administrators could act, not just the procedures they must follow before acting. The procedural requirement that administrators state their reasons follows from a substantive requireinent that they act only reasonably; as I indicated in the last Sections, the procedural requireinent of a reasons statement makes sense only if there is a concomitant requirement that the reasons voted upon be substantively acceptable. Roth, it seems to me, contains an implicit rejection of a requirement that the government act "only fairly and reasonably."

62. See J. Nowak, R. Rotunda, \& J. Young, Constitutional Law 404 (1978).

63. 408 U.S. at 588 (Marshall, J., dissenting).

64. It is theoretically possible to enforce a substantive requirement of administrative rationality without requiring a reasons statement. The problem arises when the plaintiff can show that the administrator acted "irrationally," without the aid of a required statement of reasons. For example, Roth might produce substantial proof that the chairman had fired him because he did not like Roth's necktie. A court inight feel that reversing the administrative decision in such cases would not threaten the exercise of legitimate administrative discretion.

The problem with this, however, is that the court can never tell when it is dealing with a "necktie" case or a real "exercise of intuitive discretion" case without a plenary trial. Accordingly, permitting relief in "necktie" cases would require, as a practical matter, that administrators be able to articulate and defend their reasons in every case, for plaintiffs could always allege that administrators' actions were insufficiently rational to withstand the substantive standard of rationahty. In other words, a substantive rationality requirement would force the administrator to be 
Before I turn to that argument, I ought to emphasize one point. Roth's deference to administrative discretion does not authorize the use of that discretion to interfere with substantive rights protected by the Constitution. In Roth, for exainple, the case was remanded for the purpose of determining whether Roth's nonrenewal was in retaliation for his criticism of the university. In Perry, the Court made a special effort to reaffirm this important principle: "[E]ven though a person has no 'right' to a valuable governmental benefit and even though the government may deny him the benefit for any number of reasons, there are some reasons upon which the government may not rely. It may not deny a benefit to a person on a basis that infringes his constitutionally protected interests ...."65 Roth does not interfere with this substantive protection-but it does refuse to go further.

This is not objectionable. Many other government decisions are unencumbered by a general, judicially enforced rationahty requirement-decisions in which a claim of irrationahity is similarly unavailing unless specific constitutional protections are implicated. I will discuss a few examples, not because they are identical to Roth, but because by and large they represent analogous examples of judicial deference to executive and legislative discretion.

Prosecutorial discretion provides a leading and fairly obvious example. The prosecutor's decision to prosecute-a decision with enormous impact upon the defendant-is reviewable only where the defendant claims that it was "based upon such impernissible considerations as race, rehgion or the desire to prevent [defendant's] exercise of constitutional rights." 66 If the prosecutor's behavior does not violate any such constitutional rules, he is free in any case to prosecute or withhold prosecution for any reason, or for no reason. ${ }^{67}$ The reasons for this complete deference are similar to those which I advanced in Section $\mathrm{A}$ as justification for the Roth rule. As one commentator put it: "Review is considered inappropriate out of traditional deference to the prosecutor's freedom in charging . . . ."68

Another prominent exainple of restraint in the imposition of judi-

prepared to produce and defend a reasons statement to the plaintiff-in court, if not through administrative channels.

Adoption of a substantive rationality requirenent, then, would lead to the identical problems that plagued adoption of the reasons stateinent rejected by Roth. Consequently, even if Roth does not explicitly reject a substantive requirement of rationality, such a requirement would be so inconsistent with its rejection of a reasons statement that we can safely assume that its rejection is at least implicit in Roth.

65. 408 U.S. at 597.

66. United States v. Berrios, 501 F.2d 1207, 1211 (2d Cir. 1974).

67. See Gifford, Equal Protection and the Prosecutor's Changing Discretion: Suffering an Ideal, 49 GEO. WASH. L. REv. 659, 660-71 (1981).

68. Id. at 663 . 
cial scrutiny is the standard of review applied to jury findings. Once it is determined that a case was properly given to the jury, there is absolutely no review of the underlying reasons for the jury's decision. Not only is a statement of reasons not required, it is not permitted: the rule prohibiting juror testimony regarding the jury's deliberations is widely viewed as a means of protecting the jury's right to arrive at its decision by any means it wishes to use. ${ }^{69}$ Indeed, it is the jury's ability to act without having to give reasons for its decisions that inany view as its main attraction. ${ }^{70}$

The political question doctrine is another exainple of a doctrine designed to shield discretionary governmental decisions from judicial imquiry into their reasoning. The notion that certain matters are not justiciable because they are remitted to the unreviewable discretion of the legislative branch has been with us since at least $1849 .{ }^{71}$ The doctrine's deference to the legislature is strikingly similar to Roth's deference to the administrator. The two doctrines rest upon similar policies-policies founded on the separation of powers and respect for the independent exercise of legislative, executive, and administrative discretion. ${ }^{72}$

69. In its consideration of rule $606(\mathrm{~b})$ of the Federal Rules of Evidence, dealing with testimony of jurors, the Senate Judiciary Committee defended its rejection of the House version because it "would have the effect of opening verdicts up to challenge on the basis of what happened during the jury's internal deliberations, for example where a juror alleged that the jury refused to follow the trial judge's instructions . . . ." S. REP. No. 1277, 93d Cong., 2d Sess. 13 (1974). The position expressed by the Senate (and adopted by Congress) is consistent with the well developed body of case law holding that where the jury could have reached its conclusion by a rational process (i.e., where a directed verdict should not have been granted), the trial court inust ignore proof that the jury in fact reached its result through an irrational process.

Jaines and Hazard discuss the problems associated with a strict scrutiny of the jury's deliberations:

If all that went on in the jury room were open to public and official scrutiny, either inost verdicts would fall or embarassing questions would be raised about the extent to which the law should openly tolerate and sanction deviations from the conduct and the thought processes of the ideal juror.

F. James \& G. Hazard, Civil Procedure 310 (2d ed. 1977).

Judge Frank was characteristically pungent in his expression of this same thought: "The judges feel that, were they obliged to learn the methods used by jurors, the actual workings of the jury systein would be shown up devastatingly." J. FRANK, COURTS ON TRIAL 115 (1950).

70. Cf. F. JAMES \& G. HAZARD, supra note 69, at 231: "[t]o a certain extent judges have represented ... the theoretical law and its rational implications, juries the layman's common sense and also the more or less 'passional elements in our nature'."

71. See Luther v. Borden, 48 U.S. (7 How.) 1, 38-46 (1849).

72. A final example is that the Court now defers entirely to legislatures when reviewing social and economic legislation under the "rational basis" standard imposed by the equal protection guarantee. Of course this conclusion sounds paradoxical, and it is true that the Court still purports to demand minimum rationality from the legislature. See, e.g., Duke Power Co. v. Carolina Envtl. Study Group, 438 U.S. 59 (1978). The Court's willingness to derive the purpose of the statute from its terms and to assume the existence of facts to justify the legislation, however, along with a profound, lingering sensitivity to the political reaction to the Court's decisions in the early twentieth century, have all resulted in what is in fact, if not in theory, complete deference to the 
In the areas just discussed, as in Roth, the courts do not, and should not, automatically police every decision made by the political branches. The Supreine Court has empliasized the importance of deferring to the decision of the appropriate decisionmaker, realizing that courts are no better equipped to make the appropriate decisions in those areas than the agencies whose determinations are in question.

Furthermore, Roth leaves several ways of ensuring that adininistrators do not run amok. A person who feels wronged by an administrative decision may still bring suit to prove that it was unconstitutionally notivated. Moreover, the Court's willingness to defer to the political branches is at least theoretically premised on the availability of popular review; sooner or later legislatures and the chief executive must account to the voters. Administrators, too, are subject to control, though of a different sort. Even in the bureaucracy, administrators who are given discretion unust produce some specified results; indeed, the reason for giving administrators discretion is to enhance their ability to accoinplish certain ends. To the extent that discretionary decisions are based on caprice rather than on factors calculated to achieve administrative goals, administrators will ultimately have to answer to their superiors for their department's poor perforinance. Under the scheme provided by the legislature, supervision of the administrator is accomplished through the bureaucratic chain of command. A different decision in Roth would have given the real supervisory power to the courts. Such a result would be justified only by a showing that court supervision would not only be an improvement upon the system provided by the legislature, but also such a clear improvement as to be constitutionally required. This showing has not been inade.

This concludes my functional defense of Roth. I have argued that Roth is premised on the incompatibility of true administrative discretion with judicial review. The appeal of the purportedly unburdensome reasons statement is illusory: such a requireinent would be virtually meaningless without significant judicial review, and, as the Gouge cases show, any serious judicial review would eventually dry up the meaningful exercise of administrative discretion by forcing a change in the bases of decisions. Finally, the deference given to admin-

legislative branches in the areas of social and economic regulation. See, e.g., McCloskey, Economic Due Process and the Supreme Court: An Exhumation and Reburial, 1962 SUP. CT. REv. 34, 38; W. LoCKhaRT, Y. Kamisar, \& J. ChOPER, Constitutional LAW 449 (5th ed. 1980). Though the policies supporting judicial deference to Congress and state legislatures are not identical to those supporting Roth, the similarity is substantial: both the legislative and executive branches of government need freedom to develop and act upon their discretion in those areas where discretion is appropriate; in a democracy, both branches are entitled to exercise that freedom subject to political rather than judicial oversight. 
istrators in Roth is not exceptional, but rather is the counterpart of the deference given many other government decisions.

\section{The Textual Defense: Roth Property, New Property, and the Old Property-A Response to Professor Reich}

The functional defense of Roth by itself justifies the result. I have, however, a second defense: the Roth definition of "property" is consistent with the historical and usual ineaning of the word. In my opinion, the Roth Court simply apphed its common understanding of the usual meaning of "property" to the "life, liberty, or property" formulation used in the fourteenth amendment. While the policy justifications previously advanced are surely more than incidental, I doubt very mucl that the inembers of the Court felt coinpelled to look at the problem in its functional aspect. Supreme Court Justices, like the rest of us, have at least some working sense, if not a precise definition, of the meaning of "property." Under that common sense of the word, a tenured teacher's expectation of reeinployment is property, while the untenured teacher's expectation is not. It is from this commonly shared perception that Roth emerged.

Common law cases arising im nonconstitutional contexts abound with definitions of "property." These vary largely with the purpose for which the definition is sought, but there is a common thread running through most of thein: to be property, the interest must be enforceable by law. The California Court of Appeal has said that "the word 'property' may be properly used to signify any valuable right or imterest protected by law . ..."73 The Kentucky Court of Appeal has described property "as an aggregate of rights which are guaranteed and protected by the government."74 In a similar vein, Judge Learned Hand, writing for the Second Circuit, stated that "[o]rdinarily a person has 'property' in a thing if he has untrammelled freedoin to use it as he wills and nay invoke legal sanctions to protect that freedom."75

These definitions point out that in its common usage, "property" suggests an interest one can imsist upon, rather than one whicl turns upon the good will of another. Indeed, a series of early cases, decided decades prior to the ratification of the fourteenth amendinent, said just that: "[p]roperty is defined to be . . that right which one hath to lands or teneinents, goods or chattels, which no way depend on another

73. Franklin v. Franklin, 67 Cal. App. 2d 717, 725, 155 P.2d 637, 641 (2d Dist. 1945).

74. Button v. Drake, 302 Ky. 517, 522, 195 S.W.2d 66, 69 (1946).

75. Helvering v. Elias, 122 F.2d 171, 172 (2d Cir. 1941). See also WeBster's New InternaTIONAL Dictionary 1818 (1976): "property . . . an estate in tangible assets (as lands, goods, money) or intangible rights (as copyrights, patents) in whiclt or to which a person lad a right protected by law." 
man's courtesy."76 Viewed in this context, Justice Stewart's definition of property in Roth seeins natural and unexceptional: "To have a property imterest in a benefit, a person clearly inust have more than an abstract need or desire for it. He inust have more than a unilateral expectation of it. He nust, instead, have a legitimate claim of entitleinent to it."77 If he has a "right" to it, it is "property"; but if his expectation depends on an administrator's discretion, the state has not given the type of untrammelled right traditionally defined as "property." Roth correctly defined such a benefit as soinething less than property.

What is the alternative to such a definition? In two widely noted articles pubhished in the mid-1960s, Professor Charles Reich proposed a different approach to property. ${ }^{78}$ Justice Brennan quoted these articles in his Goldberg opmion, ${ }^{79}$ and the Goldberg atteinpt to define constitutional "property" is largely based upon thein. An examination of Reich's ideas shows that it was Goldberg, and not Roth, which constituted a departure froin the common historical understanding of "property."

Reich's thesis was that the expectation of government benefits had replaced traditional forms of property as the primary source of personal wealth. It was therefore incumbent upon the Supreme Court consciously to invest these expectations with the characteristics of traditional property, so that the expectations could serve functions formerly performed by traditional property. There were two essential premises to Reich's conclusion, one explicit and the other imphicit. The first was that property should be seen "not as a natural right but as a construction designed to serve certain functions . . .."80 This conception of property is sharply at odds with the underlying assumptions of our system of political, economic and philosophical beliefs. More importantly, the constitutional provisions thenselves were apparently intended to protect the very natural-right property rejected by Reich. ${ }^{81}$

The second aspect of Reich's proposal is implicit, but it is even more troublesoine than the first. Reich argues that traditional property has evolved froin state largess to defensible right, and that therefore contemporary forms of largess also ought to be transformed into prop-

76. See Jackson v. Housel, 17 Johns. 280, 283 (N.Y. Sup. Ct. 1820). See also Reed v. Inhabitants of Belfast, 20 Me. 246, 249 (1841) (quoting 5 JACOB's LAW DictionaRY 322 (1811)); Stief v. Hart, 1 N.Y. 20, 24 (1847) (same).

77. Roth, 408 U.S. at 577 (1972).

78. Reich, supra note 8; Individual Rights, supra note 20.

79. Goldberg v. Kelly, 399 U.S. at 262 n.8.

80. Reich, supra note 8 , at 779 .

81. This is shown by Williams, Liberty and Property: The Problem of Government Benefit, 12 J. Legal Stud. 3 (1983). 
erty. ${ }^{82}$ He uses, as an important example, the homestead acts of the nineteenth century. ${ }^{83}$ These acts transformed a large portion of the nation's poor into a new, powerful, propertied class; in Reich's terms, these acts gave the poor "individual stakes in the commonwealth." 84

Reich urges a similar transformation with respect to less tangible forms of government largess. He believes that today's poor should be given the same sort of rights in intangible benefits that the poor of the nineteenth century were given in federally owned arable land, so that they, too, will develop the sort of independence and political power that came to midwestern farmers through the loonestead acts. It is imphicit in his proposal that this be accomplished by the Supreme Court's adoption of what may now be referred to as the Goldberg approaclr.

The problem with Reich's proposal is not its goal so much as the branch of government to which it is addressed. The changes contemplated by his proposal are changes of the most profound political and social consequence. They implicate nothing less than the redistribution of economic and political power anong the citizens of this nation. Reich calls for political decisions, decisions which in our system are not committed to the courts. The original homestead acts were adopted by Congress, not by the courts; any further redistributions should also be made by the political branches of government, operating in response to the pushes and pulls of the political system.

What Reich and Goldberg contemplate is something fundamentally different: a redefinition and consequent redistribution of property by the Supreine Court. If the Goldberg approach had prevailed in Roth, the Supreme Court would liave given all government employees a property right in their jobs. Flexibility in the hiring and firing of employees is a right of tremendous economic value; the consequence of a Goldberg-type decision in Roth would have been the forced transfer of that right froin the government (and ultimately froin the population at large) to the employees, a transfer no less dramatic and no less costly than the adoption of a tenure system by the political branches-a judicially created homestead act.

The right to new property and the power that comes with it should be given ultimately by the people, not by the Court. The Constitution intended courts to protect property, not to create it. Because Roth preserved the traditional roles of states and courts in the creation and protection of property, it was correct. Because adoption of Reich's approach would drastically alter those roles, it is to be avoided.

In suin, Roth's definition of "property" was substantially consis-

82. See Reich, supra note 8, at 787.

83. See id.

84. See id. 
tent with the traditional and usual definition of property. The alternative, with which the Court experimented in Goldberg, would have substituted the Supreme Court for the political branches of the government as the ultimate arbiter of the distribution of this nation's resources-and would have done so on the basis of an economic and pohitical theory rejected by a vast majority of our people.

\section{B. In Defense of Perry: $A$ Response to the Arnett Plurality}

The preceding Section responded to the arguinent that $R o t h$ did not go far enough. I now turn to an objection from the other side-that Perry went too far by giving courts the final say over both whether the state has actually created a fourteenth amendinent property right and the procedures due to the recipient of such a government benefit. I disagree: Perry is consistent with a long line of Supreme Court cases interpreting the due process clauses to require that the courts be the final arbiters of the procedures necessary to protect property - and that courts be free to readjust the procedural schemes provided by the states.

Before making this defense, however, I want to deal with a possible objection that a defense of Perry is inconsistent with a defense of Roth. I have argued that Roth's narrow rejection of a reasons requirement for discretionary government benefits was a close brush with disaster. ${ }^{85}$ How can I then defend Perry, which upheld a requirenent that the government provide not only reasons, but also a hearing, before terminating a property benefit-even when the legislature has already decided not to provide reasons and a hearing? ${ }^{86}$

The key distimction, in ny view, is that the adinmistrative decision in Roth was meant to be discretionary, and that proceduralizing it therefore would have changed the substantive criteria on which the decision was based. In Perry, the einployer had eschewed the use of subtle discretionary and intuitive factors, and had chosen instead to define the right in terms of discrete, factual criteria. Where the state has conditioned its own future action upon the existence of specified facts, even if it has not provided for reasons and a hearing, imposing these procedural requirements will not change the substantive bases of the adininistrator's decision. ${ }^{87}$ Judicialization will not interfere with discretion,

85. See supra text accompanying note 61 .

86. It does not appear that the legislature in Perry actually considered the questions of procedural protection. In Amett, however, a majority of the Court correctly read Perry as requiring procedural protections even where the legislature had carefully considered and rejected them. See supra text accompanying notes 33-40.

87. If "cause" is defined as including a subjective basis like "general inefficiency," adding a procedural requirement will change the substantive basis for disınissal. See supra text accompanying notes 57-60. For that reason, where "cause" is seriously intended to include such a subjec- 
because the state has already denied the administrator the ability to exercise it; judicialization will therefore not have the disastrous effect described in my defense of Roth.

I do not pretend that the added procedural requirements do not have a substantial effect, even on non-discretionary decisions. Nevertheless, the differences in this regard between Perry and Roth are dramatic. In Perry, the employer has decided to keep the teacher in the absence of some serious violation of standards. Increasing the procedural requirements for firing a teacher will increase the difficulty of demonstrating such a violation. The result will be a change in the seriousness of the violations necessary to cause a discharge, since minor violations do not tend to be as easily provable as serious violations. In effect, adding procedure changes the standard for dismissal froin "moderately serious cause" to "quite serious cause." This is, of course, a inajor change in the substantive bases available to the administrator. Still, it is not nearly so serious a change as that which would have resulted from requiring a "reasons" statement in Roth: there the change would have been from "any reason, including an intuitive hunch that a better person might at soine point in the future be found for the position" to "some significant (and demonstrable) deficiency in the einployee's performance."

These differences between Roth and Perry seein to me inuch more than the difference between "a hittle more [and] a little less." 88 Perry makes the consequences of giving tenure more serious, but leaves the government free to have a probationary period in which to decide whether or not to grant tenure, and free to choose not to have tenure at all. The opposite result in Roth, on the other hand, would have resulted in the virtual abolition of probationary government employment; all government employees would have been, if not tenured, at least semi-tenured. That, in my opinion, would have resulted in a drastic change in the nature of government employment.

Another way of understanding the difference between Perry and $R o t h$, between increasing procedures for those already tenured and requirmg procedures for those not yet tenured, is to analogize it to the difference between procedural decisions and substantive decisions. It cannot be said that the decision in Perry was without major substantive impact, nor could it be said that the results of a different decision in Roth would not have been in large part procedural. Substance and procedure are not, to quote Justice Frankfurter's meinorable phrase, "a

tive basis, the benefit should not be viewed as "property." See Arnett v. Kennedy, 416 U.S. at 186 (White, J., concurring and dissenting).

88. International Shoe Co. v. Washington, 326 U.S. 310,319 (1945). 
great divide cutting across the whole domam of law."89 As I have shown, though, the large substantive impact in Roth was simply not at risk in Perry.

Having responded to the objection of inconsistency, I now turn to my mam defense of Perry. Justice Rehnquist expressed the main argument against Perry in his opinion in Arnett: a government beneficiary should not be able to pick and choose ainong the provisions that grant him his benefit, accepting the fruits of the substantive provisions, but rejecting the burdens of the procedural provisions; ${ }^{90}$ he should be required to "take the bitter with the sweet."

Perry's rejection of this argument is consistent with one hundred years of settled Supreine Court practice. Three prominent examples help make this point. In Pennoyer v. Neff, ${ }^{2}$ Neff had obtained his property by homesteading. He took his property subject to the laws of Oregon, and, pursuant to those laws, his former attorney obtained a judginent and executed against the property. The Supreine Court was willing to invalidate the judgment and the execution, because Oregon's laws did not require the attorney to attach the property at the coinmencement of the proceeding. Neff was permitted to take the substantive benefits of Oregon law, and at the same time demand improvement of the Oregon procedures purporting to condition those benefits.

Mullane v. Central Hanover Bank \& Trust Co. ${ }^{93}$ provides a more recent example. New York adopted special legislation that permitted trustees to commingle trust funds, thus making it feasible for New York banks to administer small trusts. An important part of this statute provided that the trustee could obtain a decree settling all liabilities against the beneficiaries once every three years. In adopting this statute, the legislature had considered the procedures to be used, and had provided that notice to the beneficiaries could be given by publication. The Supreme Court held that the due process clause required that inore extensive effort be inade to give notice, thereby increasing the beneficiaries' protection beyond that given them by the statutes they (or their settlors) had chosen to rely upon.

Finally, in Fuentes $v$. Shevin, ${ }^{94}$ the Supreme Court invalidated

89. Guaranty Trust Co. v. York, 326 U.S. 99, 108 (1945).

90. Justice Rehnquist limited his argument to cases in which the legislature had considered the extent of the procedures at the same time that it considered the scope of the right. See supra text accompanying note 37. The logic of his argunent, however, would cover cases in which the legislature had not unade such a consideration, but subsequent administrative or judicial cominon law had established the unavailabihty of procedural protection.

91. 416 U.S. at 153-54.

92. 95 U.S. 714 (1878).

93. 339 U.S. 306 (1950).

94. 407 U.S. 67 (1972). 
Pennsylvania and Florida statutes providing for ex parte prejudgment seizure of personal property. These statutes, at least by implication, gave installment sellers the right to seize goods witlout notice whenever the seller believed the purchaser to be in default-an important procedural protection of the seller's property interests in the chattels. As in Perry, the Fuentes Court was willing to rearrange the procedural terms that otherwise would have controlled the contractual relationship between the parties; it let Mrs. Fuentes avoid the bitter while keeping the sweet.

None of these cases dealt with government benefits. Even Mrs. Fuentes' equitable interest in her stereo was "traditional" property, at least in the sense that it was not government largess. This, however, does not undermine the clear implications of these holdings: the legislature may have substantial control over substantive inatters, but the Supreme Court is the final arbiter of procedural sufficiency, and will not hesitate to alter procedural arrangeinents the state has created. Perry represents the Supreme Court's determination that its general supervision of procedure should be extended to test the constitutional sufficiency of procedures accoinpanying grants of government benefits. This determination was correct: once a right has attained the status of fourteenth amendinent property, the extent of process required by the fourteenth amendment should not depend on whether it is traditional property or an expectation of a government benefit. The only basis for distmguishing the substance of the right in Perry from those in Pennoyer, Mullane, and Fuentes is that the former was an expectation created directly by the government. This fact, by itself, should not be sufficient to deprive the individual of protections that would be available to someone whose expectations originated in a nongovernment source.

There is one other point made in Arnett that I want to refute before leaving iny discussion of the case. Justice Rehnquist argued that legislation granting rights accompanied by some procedure sliould be seen as a contract between the state and the beneficiaries. Under this "contract," the beneficiary, in return for getting the right, agrees to the limited procedural protections provided by the state. The Fuentes opimion addressed this point. It strongly suggested that a waiver provision in a consumer contract could be enforced only if it were demonstrated that the buyer had knowingly agreed to the provision, and had done so im individual negotiations between parties of equal bargaining power. ${ }^{95}$ Even if Perry and Arnett can be viewed in contractual terms, it can hardly be said that either Robert Sindermann or Wayne Ken-

95. Id. at $94-95$. 
nedy " "voluntarily, intelligently and knowingly" waived the right to procedural protection of his expectation, inerely by accepting the state's largess. The legislation that ostensibly limited the protections available to Sindermann and Kennedy was entitled to no greater effect than the legislation and the private agreenents that purported to limit the protections available in inany of the Pennoyer-Mullane-Fuentes line of cases. Any attempt to apply a contract analysis to this kind of case inust, like the broader challenge to the courts' roles as guardians of procedure, ultimately fail.

This concludes my defense of Perry. I have argued that the line drawn by Perry and Roth is the natural extension of the substanceprocedure dichotoiny the Court has applied to traditional property for over a century. Perry is consistent with, and perliaps even required by, a long line of Supreine Court cases. Finally, Justice Relınquist's contractual waiver inodel, even if applicable, would not require a different result: tested by the standards appropriate to contractual waivers of constitutional rights, inerely accepting government benefits would hardly be enough to justify a conclusion that the due process clause should not apply.

\section{III}

\section{A Response To The Scholarly Critics}

A substantial amount of scholarship has been devoted to condemning Roth and Perry. Virtually all of it concludes that Goldberg delineated the right approach to defining the reach of the due process clause, and that Roth (but not Perry) was therefore incorrect. ${ }^{96}$ The criticism of Roth in the scholarly journals has included a number of serious arguinents against the Court's position. Insofar as the arguments I have already inade do not answer these commentators, this Part provides inore explicit responses.

\section{A. Criticism Based on History}

A number of authors liave claimed that Roth represented a sharp break with an earlier, nore expansive approach to the definition of the phrase "life, liberty or property" in the fourtcenth ainendment. In his incisive discussion of judicial review, Professor John Hart Ely observed that "[t]he phrase 'life, liberty or property' was read as a unit and given an open-ended, functional interpretation, which meant that the government couldn't seriously hurt you without due process of law."97 In an

96. Cf. J. Ely, DemocraCY and Distrust 19 (1980) ("The [Roth] line of decisions has been subjected to widespread scholarly condemnation, which suggests that sometime within the next thirty years we may be rid of it.").

97. Id. 
important discussion of the Roth line of cases, Professor Monaghan emphasized Roth's break with the past:

Prior to Roth, Supreme Court definitions of "liberty" and "property" had amounted to taking the words "life, liberty or property" as a unitary concept embracing all interests valued by sensible men. After Roth, however, each word of the clause must be examined separately; so examined, we find that they do not embrace the full range of state conduct having serious impact upon individual interests. ${ }^{98}$

To the intent of these authors to criticize Roth for its perceived break with the past, I have two responses. First, it is difficult to defend the Warren Court's brave innovations ${ }^{99}$ and at the same time urge a strict respect for stare decisis. Indeed, one senses in the criticism a "ratchet"100 approach to respect for precedent in the constitutional law context: innovation is appropriate where it expands personal liberties, but not where it contracts them.

The sccond and weightier response is that Perry and Roth did not contract the protection required by the due process clauses, as these authors charge. It is Goldberg, and not Perry-Roth, that in fact represented a radical departure from the historical approach to due process. While it is true that the Court lias spoken expansively of the reach of the due process clause, if we examine closely the contexts in which the Court has been willing to act on its broad statements regarding the meaning of "life, liberty or property," we see that Roth was considerably more consistent witl the past than Goldberg. The older cases most frequently cited for an expansive view of the due process clauses dealt with the meaning of "liberty." 101 The Court sharply limited the reach of these cases with the right-privilege doctrine. The Court used its broad definition of liberty, not to find a protectable right to government benefits, but rather to protect economic interests, sucli as the "liberty"

98. Monaghan, supra note 2, at 409.

99. Even so staunch an advocate of judicial restraint as Professor Monaghan seems kindly disposed towards judicial innovation when he agrees with the result. See, e.g., Monaghan, The Supreme Court 1974 Term - Foreword: Constitutional Common Law, 89 HARv. L. Rev. 1, 43 (1975) ("In short, one could with ingenuity impose on the states through constitutional common law all the best features of the Federal Rules of Criminal Procedure and the Federal Rules of Evidence."); see also J. ELY, supra note 96, at 73-74 (defending the Warren Court's unprecedented activism in the areas of political expression and association, voter qualification and inalapportionment, and protection of "equal treatment for society's liabitual unequals"-all because these were process-oriented rather than value-oriented decisions.)

100. This term was aptly used by Professor William Cohen to describe Justice Brennan's suggestion in Katzenbach v. Morgan, 384 U.S. 641, 651 n.10 (1966), that while Congress had discretion to increase the scope of the equal protection and due process clauses, section 5 of the fourteenth amendment "does not grant Congress power to exercise discretion in the other direction . . . Cohen, Congressional Power to Interpret Due Process and Equal Protection, 27 STAN. L. REv. 603, 606 (1975).

101. Meyer v. Nebraska, 262 U.S. 390 (1923), is famous for its broad definition of liberty. 
to work more than sixty hours a week. ${ }^{102}$ The cases cited by these "historical" critics of Roth would never have been used to protect private expectations of government benefits.

The criticism that Perry and Roth contracted traditional protections is not only unfounded, but actively wrong. Perry and Roth did break with the past, but not by making doctrine more restrictive: they actually expanded the meaning of the due process clause. Prior to Roth, case after case denied the existence of a constitutionally protected property interest in goverinent employnent. ${ }^{103}$ The Court was historically and consistently very sensitive to the importance of the executive's power to remove employees, tenured or untenured. Perry was unusual because it hampered the exercise of that power when tenured employees were involved, thereby expanding the constitutional protection for property rights in government jobs. ${ }^{104}$

In sum, the criticism that the Roth approach is a complete break with a more solicitous past is unsupported by the cases. Worse than that, the criticism is perverse: if Perry and Roth are subject to any criticism on the basis of history, it is that they expanded, rather than contracted, the scope of the "property" protected by the due process clauses of the Constitution.

I should address another, somewhat different historical argunient. It may be thought that $R o t h$ is inconsistent with the line of cases culnninating in Fuentes $v$. Shevin. Under state law, the seller in Fuentes retained title to the goods until the final payinent had been made. Any right the purchaser had to possession terminated upon her default; thus, a defaulting purchaser did not have a "property right" in the goods. The Fuentes Court, lowever, was willing to find a protected property interest, even though there was no such interest under state law. It could be argued that this ruling is inconsistent with the Roth holding that the Court should defer to the states when defining property for the purposes of the fourteenth amendment.

This argument misreads both Fuentes and Roth. Fuentes did not hold that the purchaser had a property interest in the goods. The very question at issue in the replevin action was whether or not the purchaser had such an interest. The purchaser's right to continued possession of the goods turned upon the answer to a very specific question: had she defaulted in her payments? If so, was lier failure to pay ex-

102. See, e.g., Lochner v. New York, 198 U.S. 45 (1905).

103. See Frug, supra note 57, at 961-70, and cases cited therein. See also Monaghan, supra note 2, at 435 ("Although there are cases which can be read to the contrary, time seems to have yielded a consensus that the due process clause itself does not 'create' any property interests.").

104. Frug, supra note 57, at 961-62.

105. 407 U.S. 67 (1972). 
cused by the seller's breach of an implied warranty to repair the product in question? ${ }^{106}$ These are perfect examples of specific criteria the existence or absence of which determine whether a fourteentli ainendment property right is involved. Under Roth, as under Fuentes, an expectation that turns upon the existence of sucl criteria is "property." Therefore, Fuentes' discussion of property is not only entirely consistent with Roth, but can almost be said to have anticipated it. ${ }^{107}$ As a result, this historical argument, too, ultimately fails.

\section{B. The Court's Role Under the Due Process Clause: The Positivism Criticism}

A number of scholars have argued that Roth is wrong because the Court, and not the states, should have the ultimate responsibility for defining "property" under the fourteenth anendment. ${ }^{108}$ In their view, the deference of Roth gives back to the states what the fourteenth amendment was supposed to take from them. The fourteenth amend-

106. Id. at 87 n.17.

107. In some states, courts engaged in the division and distribution of marital property upon divorce are given a very wide discretion, approaching that of Roth's political science chairman. Under Roth, it might be argued, sucl distribution does not implicate the due process clause, because each spouse's expectation turns upon the virtually unfettered discretion of the judge. In such situations, Roth would not prohibit the judge from proceeding without notice, nor froin ex parte communications with one spouse. And if Roth would not prohibit these actions-whicls we know intuitively must be prohibited-then Roth must be wrong.

While I agree that Roth does not reach this situation, it is largely because there are factors at play in private hitigation which simply do not exist in the context of the disbursement of governmental largess. First, where the government is acting solely as referee between two private parties, interfering with its flexibility does not implicate its "very ability to function." See Frug, supra note 57, at 992.

Second, and more important, the risk of substantial (perhaps grievous) unfairness froin ex parte proceedings is much greater in the adjudicatory context, than in the context of the government's actions as disburser. In the forner context, the decisionmaker will have no information of its own, and will therefore be subject to being seriously misled by a private party intent upon using the coercive power of the state's courts to achieve his own private ends-ends whicli are almost by definition adverse to those of the affected individual. In contrast, where the government is acting as the disburser of benefits, the decisionmaker typically las acquired his own information; this is not to say that requiring a hearing would not usually add to that information and correct inaccuracies. But as a relative matter, the need for "notice and an opportunity to appear" seems mucl greater in the adjudicatory 'context. And it should be noted that this difference will be particularly noticeable where the determination regarding disbursement turns upon an exercise of discretion by an administrator, because in suclı a situation, the disputed facts presnmably play a sinaller role in the ultimate decision.

The Supreme Court recognized this difference between private and public actions in CaleroToledo v. Pearson Yacht Leasing Co., 416 U.S. 663, 679 (1974), where it refused to extend Fuentes to require preseizure notice and hearing, in the context of a yacht seized for carrying contraband: "[U]nlike the situation in Fuentes, seizure is not initiated by self-interested private parties; rather Commonwealth officials determine whether seizure is appropriate under the provisions of the Puerto Rican statutes."

108. See, e.g., Monaghan, supra note 2, at 440; Tushnet, The Newer Property: A Suggestion for the Revival of Substantive Due Process, 1975 SUP. CT. REv. 261. 
ment, they reason, was adopted to protect imdividual rights from state deprivations; by giving the states the authority to define which rights will be protected from their own deprivations, and which will not, the Roth rule has all the logic of giving the fox the keys to the henhouse. In short, these scholars argue that the Suprene Court should determine for itself what imterests are "property" for purposes of the fourteenth amendment.

Professor Monaghan raises this issue with an interesting hypothetical:

Suppose that a state motor vehicle statute invested autoinobiles with all the attributes of property as that term is generally understood, but also provided that no person who bought a car after the statute was passed would be deemed to have a "right to continued" ownership as against the state. ${ }^{109}$

Monaghan postulates that under Roth, this statute would mean that cars are not property, since their continued possession depends wholly upon an administrator's discretion. He then argues that if faced with such a statute, the Supreme Court would surely be forced to disavow Roth and hold that the cars are property and must be protected by the due process guarantee. ${ }^{110}$ This result would in turn show that it is the province of the court, not of the states, to define what "property" isand that Roth, by trying to give the power of definition to the states, inust therefore be wrong.

Monaghan's argument is unpersuasive, not because the hypothetical law he gives us is constitutional, but because Roth in fact does leave the courts a role that would allow them, consistent with Roth, to decide for theinselves whether an interest is protectable "property" or not. First, Roth and its progeny ${ }^{111}$ do in fact reserve to the courts the determination of whether interests defined by the states are fourteenth amendment property. In other words, the state may define the incidents of a particular expectation, but it is up to the courts to decide whether this expectation is fourteenth amendment property. ${ }^{12}$

Perry provides an excellent example of this. In Perry, it is state

109. Monaghan, supra note 2, at $\mathbf{4 4 0}$ (footnote omitted). Monaghan raises this hypothetical to criticize Bishop v. Wood, 426 U.S. 341 (1976), but his point seems as fairly to be taken in criticisin of Roth itself.

110. Monaghan, supra note 2, at 440.

111. See, e.g., Greenholtz v. Nebraska Penal Inmates, 442 U.S. 1 (1979) (grant of parole within discretion of parole board); Leis v. Flynt, 439 U.S. 438 (1979) (discretion to control pro hac vice appearances).

112. This point is nicely made in Terrell, "Property," "Due Process," and the Distinction Between Definition and Theory in Legal Analysis, 70 GEO. L.J. 861, 896 (1982): "But Professor Monaghan erred in beheving that the Court had actually conceded this much authority to state law. Rather, the Court's approach still requires courts to determine the 'sufficiency' of any interest." 
law that would determine whether, as a substantive matter, Sindermann had an expectation of continuing einployment absent cause for termination. If he did, then the court would define his interest as fourteenth amendment property without regard to the state courts' view on that particular matter. ${ }^{113}$ Thus, while state law defines the substantive bases of particular entitlements, it is federal constitutional law that determines whether or not particular entitlements are "property."

Second, it is implicit in Roth that the "life, liberty or property" interests protected by the due process clauses include not only statecreated interests, but also interests "created" or "recognized"114 by tine Constitution itself. Roth itself provides an example. Roth alleged that nonrenewal of his current job would have a substantial adverse effect upon his ability to find another job, and that this adverse effect constituted an interference witl his liberty. The Court rejected this claim, but held that if the nonrenewal had been based on grounds whicli implicated his "good name, reputation, honor, or integrity," it would liave deprived him of "liberty," and lie would then have been entitled to notice and a hearing to clear his name. ${ }^{115}$ The point is that the Court canvassed the Constitution as well as state law to determine wlietlier Roth had a substantive interest entitled to protection under the due process clause. That the state had chosen not to protect a particular interest-here, an interest in reputation-did not by itself remove it froin due process protection.

This is the most important part of my response to the "positivist" criticism of Perry and Roth: the cases leave a substantial role for the federal judiciary in the definition of rights and interests whicls are to be protected under the due process clause. Further, it is a substantive, not simply a procedural, role. The evaluations that courts must still perform-for example, the determination of whetlier Monaghan's statute impermissibly burdens individual freedom to own automobiles-fall into areas we routinely describe as substantive, areas in whicl the Court claims no special expertise, and in which substantial deference to the state legislature is not only customary but appropriate.

113. See id. at $896-97$.

114. Cf. Meachum v. Fano, 427 U.S. 215, 230 (Stevens, J., dissenting) ("neither the Bill of Rights nor laws of sovereign States create the liberty which the Due Process Clause protects. . . . I had thought it self-evident that all men were endowed by their Creator with liberty as one of the cardimal unalienable rights."). Fortunately, it is not necessary that I decide in this Article whether the Constitution creates the right to liberty, or merely recognizes and protects a preexisting right to liberty. Whichever view may be appropriate, it is surely the ultimate responsibility of the Supreme Court to determine whether a particular imterest fits within the term "liberty," and is therefore entitled to the protection of the due process clauses.

115. 408 U.S. $573 \&$ n.12. 
Returning to Monaghan's statute quoted on page 182 and looking at how a court would examine it makes my point clear. The Court might conceivably find private ownership of automobiles so important that a statute like this, which does not treat the automobiles as property, is unconstitutional; it might hold that whether or not an individual "owned," or had the right to continued use and possesion of, a particular car, could not be made to turn on the discretion of an administrator. This question is substantive: whether there is a fourteenth amendment right to private ownership of automobiles. The importance of Roth is that it allows the Court to deal openly with such substantive questions. In doing so, the Court will be free to reject the substantive balance struck by the legislature, and it would not by so doing depart from Roth's analytical approach. All that Roth requires is that substantive decisions not be disguised as procedural questions.

Under Goldberg, by contrast, the substantive decision would be hidden in the guise of a procedural determination. By intposing a "reasons" requirement, and then reviewing the adequacy of the reasons given, courts adopting the Goldberg approach would ultimately make meaningless any particular statute's rehance on the adininistrator's discretion. But if rejecting discretion is the appropriate result, it is because allowing discretionary decisionmaking is substantively unsatisfactory; it is not appropriate that the Goldberg result be reached without recognition of that fact, and without consideration of the substantive policies at stake. This is why Goldberg is less honest and less satisfactory than the Roth-Perry approach. Perry and Roth do not preclude the mvalidation of Monaghan's statute: all they do is to provide a mechanisn for separating the substantive and procedural issues.

\section{Procedural Fairness as a Substantive Right}

In a widely noted article, Professor William Van Alstyne sought to shice through the Gordian knot of substantive rights and procedural protections by proposing that procedural fairness itself be treated as one of the substantive rights entitled to protection as liberty. Just as state action depriving a person of his freedom of movement or of his traditional property must be preceded by procedural due process, so too should state action depriving a person of his "freedom from arbitrary adjudicative procedures" 116 be preceded by procedural due pro-

116. Van Alstyne, supra note 7, at 487 . The Cahifornia Supreme Court recently expressly adopted Van Alstyne's approach. See People v. Ramirez, 25 Cal. 3d 260, 268, 599 P.2d 622, 627, 158 Cal. Rptr. 316, 320 (1979) ("freedom from arbitrary adjudicative procedures is a substantive element of one's liberty"). The court carefully rehed upon the California Constitution's due process clause, thereby precluding Supreme Court review of its decision. See id. at 265-66, 599 P.2d at 625, 158 Cal. Rptr. at 319; id. at 277-78, 599 P.2d at 633, 158 Cal. Rptr. at 327 (Richardson, J., concurring) ("Because of the close similarity in the applicable United States and California consti- 
cess-whether or not it otherwise deprives him of "property."117 It is the procedural unfairness itself, and not the deprivation caused by that unfairness, that concerns Van Alstyne. What is needed is protection against procedural unfairness, not only when the government is acting against certain defined interests, but also when it is acting "in all its protean exercises of power." 118 What is needed, and therefore at least implicit in the Constitution, is an all-encompassing protection against "an intolerable inargin of probable error," "119 "liberty-immunity from unwarranted procedural grossness." 120

Professor Van Alstyne's clever solution would simply do away with the need to decide whether the interest terminated ainounted to liberty or property under the fourteenth ainendment. If the termination lacked certain fundamental procedural safeguards, that deficiency, by itself, would trigger the due process clause. In inuch the saine way that a governmental edict transformed the result in Vietnam to "victory," Van Alstyne, by a simple declaration, would transform "procedural due process" into a substantive right protected as part of "life, liberty or property."

While there are technical problems with the details of Van Alstyne's proposal, ${ }^{121}$ his general point-that the Constitution ought to preclude all "procedural grossness"-could easily be reached from another avenue. If the words "life, hiberty or property" were read as having an all-inclusive meaning, a position not without support, ${ }^{122}$

tutional language, and to avoid insulating our decision from further review, I would rely upon the federal due process clauses. . . .). Under recent United States Supreme Court cases, appellant was entitled to the hearings provided by the majority opinion.

117. One of the inore interesting aspects of Van Alstyne's article is the contrast between the first forty pages of his artiele and his concluding discussion. In the first forty pages, Van Alstyne mounts what appears to be an effective defense of Roth, and pretty well demolishes the point with which he ultimately concludes. In the final five pages, he relies upon arguments effectively rebutted earlier on, without responding to his earlier points and without even noting the inconsistency. This may simply indicate that those of us who litigate (Van Alstyne argued as an amicus in Roth against the Court's ultimate result) are less fiexible than those of us who nerely criticize from the sidelines.

118. Van Alstyne, supra note 7, at 487 (emphasis in original).

119. Id. at 488 .

120. Id.

121. Under Van Alstyne's proposal, any governinent action that adversely affects an individual must be accompanied by appropriate procedures. This is true even when the action does not otherwise deprive the individual of "life, liberty or property." As Professor Williams has cogently observed, this construction renders the terms "life" and "property" redundant: every government action will implicate this liberty interest in procedures; whether it also implicates "life" or "property" will be irrelevant. Williams, supra note 81, at 25-26. Furthermore, Van Alstyne's approach leads to the linguistic absurdity that the Constitution prohibits the denial of due process without due process. Id. at 25; see also Saphire, Specifying Due Process Values: Toward a More Responsive Approach to Procedural Protection, 127 U. PA. L. REv. 111, 150 \& n.169, 179-80, 182-83 (1978).

122. Professor Ely provides historical sources that would support such a view. See J. ELY, supra note 96 , at 192 n.28. 
governmental deprivation of any significant expectation would implicate the due process clause. Such a reading would lead to constitutional protection against "procedural grossness," without regard to the nature of the benefit in question. Accordingly, Van Alstyne's concerns must be addressed directly.

The key to the error in Van Alstyne's analysis can be found in his discussion of Arnett. He claims that what should bother one about Kennedy's dismissal is not the fact that Kennedy lost his job, but the fact that "Wayne Kennedy was not treated fairly." 123 Later discussion shows that what he means by "treated unfairly" is "procedural grossness." 124 At bottom, Van Alstyne's position seems to be that procedural protection, like Beauty, "is its own excuse for being." 125

Van Alstyne is correct to say that Roth does not protect any substantive interest in being accorded due process for its own sake. I think, however, that he is wrong to argue that procedures are so inportant that even unprotected interests should not be infringed without some due process. It is easy for lawyers to overvalue the importance of procedural regularity. Procedural protection is too ideal, too seductive to be resisted. Look at its virtues: It is symmetrical. It is technical. It is presumably value-free, and therefore does not require the force-feeding of debatable social theories.

I agree that procedures are important, are perhaps even, as Justice Frankfurter stated, the largest part of "the history of liberty." 126 But providing procedures is not the answer in cases like Roth. Procedures are important, not for themselves and not as symbols of the perfect society, but only as a means of protecting matters of value. These inatters of value are not the procedures themselves, but the interests which they protect. If there is no sufficiently valuable right at stake, as the Court determined there was not in Roth, procedures by themselves are not valuable.

Van Alstyne's position seems to rest ultimately on the notion that, whatever the substantive outcome, the affected individual should be left at least with a "feeling of just treatment." The Supreine Court seeins to have rejected this view, not only in Roth, but also in Carey $v$. Piphus. ${ }^{127}$ In Carey, it held that the "feeling of just treatinent" (Van Alstyne's freedom from procedural grossness) was an interest entitled only to nominal protection under the due process clause, apparently

123. Van Alstyne, supra note 7, at 484.

124. Id. at 488 .

125. R. EMERSON, The Rhodora, in 9 The Complete Works of RAlpH Waldo EMERSON 38 (E. Emerson ed. 1904).

126. McNabb v. United States, 318 U.S. 332, 347 (1943), quoted in Van Alstyne, supra note 7, at 487.

127. 435 U.S. 247 (1978). 
rejecting the idea that the procedures have an intrinsic value of their own.

We should remember that Van Alstyne's proposal carries with it all the costs associated with the Goldberg approach. Furtherinore, where procedures are posited as their own goal, there would seem to be a very real risk of creating the sort of monster which existed in eighteenth century England, largely as a consequence of proceduralism. On balance, the epliemeral benefits of Van Alstyne's proposal liardly seem worth these substantial costs.

\section{Protection of Dignitary Interests}

Another, related criticism of the Roth approach lias been that it does not sufficiently protect affected individuals" "dignitary interests." This criticism is founded on a notion of the importance of individuals' perceptions of their own self wortli ${ }^{128}$ - an interest protected by what Professor Frank Michelman calls the "informal" use of procedures. ${ }^{129}$

Michelman's criticism of Roth turns upon its refusal to acknowledge and protect what he calls nonformal goals. Tliese are goals relatmg to the individual's personal feelimgs about himself, the "communal or fraternal aspect of [his] social life,"130 and "his relationship with fellow members of the group."131 Imposmg a reasons requirement miglit fulfill some of these nonfornal goals; as Michelman says, it could fill "a potentially destructive gap in the imdividual's conception of himself." 132 Michelman, then, would impose procedures not because they might have some substantive benefit but because the procedures themselves serve the goal of making the mdividual feel better about himself.

The view has an obvious attractiveness. In a time of ever worsening individual alienation, and of an increasmgly large, bureaucratic, and impersonal government, this view would impose a constitutional mandate of civility, courtesy, even lumanity upon institutions not re-

128. See L. Tribe, American CONSTitutional LAw 502-03 (1978); Dauer \& Gilhool, The Economics of Constitutionalized Repossession: A Critique for Professor Johnson, and a Partial Reply, 47 S. CAL. L. Rev. 116, 148-49 (1973); Kadish, Methodology and Criteria in Due Process Adjudication-A Survey and Criticism, 66 YALE L.J. 319 (1957); Karst, The Supreme Court, 1976 Term-Foreword: Equal Citizenship Under the Fourteenth Amendment, 91 HARv. L. REv. 1, 8-9 (1977); Kirp, supra note 47; Mashaw, The Supreme Court's Due Process Calculus for Administrative Adjudication in Mathews v. Eldridge: Three Factors in Search of a Theory of Value, 44 U. CHI. L. REv. 28, 49-50 (1976); Michelman, supra note 47; Pincoffs, supra note 47; Subrin \& Dykstra, Notice and the Right to be Heard: The Significance of Old Friends, 9 HARV. C.R.-C.L. L. REV. 449, 457 (1974); Summers, Evaluating and Improving Legal Processes-A Plea for "Process Values," 60 Cornell L. Rev. 1, 23 (1974); Tribe, Structural Due Process, 10 HaRv. C.R.-C.L. L. Rev. 269, 306-07 (1975).

129. Michelman, supra note 47.

130. Id. at 128 .

131. Id. at 131 .

132. Id. at 127 . 
nowned for those characteristics. Furthermore, it is claimed, imposing such a requirement would cost nothing: it would simply inake the administrator talk to an imdividual before taking action affecting him.

The first problem with the "dignitary interests" approach is a practical one, and one which seems to me imsurmountable. Professor Pincoffs identifies it im the very first sentence of his essay on due process: "It is impossible to legislate decency im human relations." 133 It is understandable that in this litigious day and age we should be tempted to look to the courts even for a requireinent of courteous treatment, but as Professor Michelman himself recognized, ${ }^{134}$ this asks from the courts something even they can not provide.

There is a second sense im which this proposal seeins unreahistic. It appears to respond to a model of an mdividual confronted with an impersonal, autocratic, and above all unexplaimed administrative decision that leaves him bewildered and confused as to what possibly could have lrappened-for example, a teacher receiving an unexpected pink slip in the mail. This model simply does not fit reality. Administrative decisions of this type generally do not coine as surprises. By the time the matter lias degenerated to the point where outright dismissal or nonrenewal is likely, there has usually been substantial discussion and disagreement, and both sides liave developed a fairly good idea of the other's views. ${ }^{135}$

Another unreahistic premise of the "dignitary interests" argument is that the affected individual values the administrator's opinion. This is simply not the case. By the tinie an administrator fires an employee, the two are usually deeply and irreconcilably antagonistic toward each other. The notion that the employee needs the personal exchange witl the administrator to plan future self-improvement, to enhance his selfrespect, or to increase his admiration for the workings of government is based on an unrealistic view of liuman relationships. Revelation of and participation in the decisionmaking process may be very iniportant

133. Pincoffs, supra note 47 , at 172 .

134. Michelman, supra note 47 , at 149-50.

135. Roth publicly refused to ineet with the University admininistration. See Petition for Certiorari, Appendix at 127-28, Roth. In Perry v. Sindermann the administration had communicated its disapproval to Sindermann formally and informally, both sides were quite clear about the other side's views, and (by the time he was fired) there seems to have been substantial enmity between thein. In Arnell, of course, Kennedy was fired for publicly accusing his superior of bribery. As did Roth, Kennedy refused the opportunity available to him to meet personally with his superior. Though the records in the lower court cases discussed to this point are not available to me, the courts' factual discussions suggest similar fact patterns-at least with regard to pretermination discussions, if not also personal enmity. See Tupper v. Fairview Hosp. \& Training Center, 276 Or. 657, 556 P.2d 1340 (1976); Hammer v. Oregon State Penitentiary, 276 Or. 651,556 P.2d 1348 (1977); Gouge v. Joint School Dist. No. 1, 310 F. Supp. 984 (W.D. Wis. 1970) (discussed supra text accompanying notes 48-56). 
for protection of the individual's substantive rights, including his right not to be be discharged for substantively impermissible reasons, but they are hardly likely to provide the introspective benefits claimed to be so important.

The real solution would be to convince those administrators who do not respect the people they deal with to do so; to teach those administrators who are not already humane and compassionate to be so; and to force those administrators who do not act openly, honestly, and fairly to act so. The task is not to generate more communication, but to improve the quality of the relationships underlying that communication. Such a task could not be more clearly beyond the reach of judical decrees. ${ }^{136}$

I have so far treated the premise of the inherent dignitary rights proposal as an empirical one-namely, that adoption of the proposal will end up making affected individuals feel better about themselves. This may miss entirely the point made by inany of the writers in this area, who argue that courts should require administrators to reveal reasons for their decisions and allow employee participation in them because doing so makes a moral statement about the importance of the individual in society. These commentators perceive the government's failure to provide participation and revelation as a serious noral statement. ${ }^{137}$ The central principle is that a person must be treated not as a means but as an end in himself. ${ }^{138}$ Revelation and participation are valuable not only because they support this goal by encouraging the individual to recognize that he is important in his own right, but also because they symbolize the government's ultimate inorality.

I disagree with those who see the Constitution as requiring procedures for their symbolic value, not because the merits of the argunient are flawed, but because the institutional structure of our government gives each branch its own role. By and large, legislatures intend government prograins to operate without courts. When courts intervene anyway and overrule the legislative judgment as to how inuch process is due, they should do so only for weighty and clearly established reasons. They should be reasonably certain their actions will, in some tangible fashion, ease a problem that cries out for a solution. Their reasons for intervening, if not based directly on the tcxt of the Constitution, should at least rest on some administrative legal doctrine.

Failing to recognize this, the "moral" theorists go too far. They

136. Mashaw, The Management Side of Due Process: Some Theoretical and Litigation Notes on the Assurance of Accuracy, Faimess and Timeliness in the Adjudication of Social Welfare Claims, 59 CoRnell L. Rev. 772 (1974).

137. Pincoffs, supra note 47 , at 180.

138. See Michelman, supra note 47 , at 131. 
urge sweeping reforms, not because individuals are actually being harmed by insufficient process, but because the amount of procedure reflects a conception of the relationship between individual and governinent inconsistent with their own. As important as I concede symbols to be, I do not think it the business of the Supreme Court to impose them upon the legislatures of the states.

\section{E. Some Final Arguments}

Three additional arguinents made by scholarly critics of $R$ oth merit brief consideration. The first is that procedural protections are necessary to ensure against dismissals based upon grounds prohibited by the first ainendment. For example, District Judge Doyle stated im his Roth opinion: "Substantive constitutional protection for a university professor agamst non-retention . . . is useless without procedural safeguards." 139 Professor Van Alstyne has responded convimcingly to this approach. He notes that "for courts to use the opening wedge of the first amendinent as a means of requiring at least some mimimum of adjudicative process throughout the public sector would be a poor case of allowing the tail of the first amendment to wag the dog of the new property." 140 Van Alstyne is right. Because a generalized reasons and hearing requirement would create tremendous upheaval, it would be inappropriate to impose such a requireinent throughout the entire administrative branch of government $\mathrm{m}$ order to avoid the few decisions based on impermissible discrimination against first amendment activities. Such a requirement could only be justified by a presumption that government illegality is pervasive-a presumption that neitlier the courts nor the people are likely to accept. This is especially true because, as I argued earlier, a decision that is purportedly made on impermissible grounds can always be challenged.

A second objection, posed by Professor Stephen Williams, is that the Perry-Roth analysis creates a peculiar dismcentive for a legislature to create substantive rights. Roth says that a legislature wishing to avoid a constitutional requirement of onerous hearings inay do so by disbursing its resources on a standardless basis, relyming entirely on unreviewable administrative discretion. Perry, then, actually penalizes the legislature for adopting standards. ${ }^{141}$

While this objection appears logically correct, as a practical inatter it seems unlikely that this disincentive will deter most legislatures. The "penalty" mvolved does not hurt the legislature itself; nor does it im-

139. 310 F. Supp. 972, 979-80 (W.D. Wis. 1970), aff', 446 F.2d 805 (7th Cir. 1971), rev'd, 408 U.S. 564 (1972).

140. Van Alstyne, supra note 7, at 475.

141. Williams, supra note 81 , at $6,14$. 
pinge upon the political process. More importantly, the situations in which the courts will require procedures are likely to be those in which the legislature would be least upset by them. It should be remembered that Perry and Roth require procedural protections only where the legislature itself has designated the recipients of the benefits in question, and not where it has left that decision to the discretion of an administrator. While requiring procedures not imposed by the legislature may run counter to the legislative intention im one sense, it does not seem seriously inconsistent with the underlying legislative goal. The legislature chose to grant certam beneficiaries a property right, and Perry's procedures have as their only goal the protection of that property and of those beneficiaries.

A third objection, raised by Professor Williams ${ }^{142}$ and others, is that the specificity of the terms of the grant does not refiect the importance of the interest and therefore should not control whether the imterest receives procedural protections. They argue that the Roth-Perry view leaves some important interests unprotected while unimportant interests are protected.

My answer to this objection lies in my arguinent that the Roth approach is superior to the Goldberg importance test. An example, however, may be helpful at this poimt. No interest could be more important than the life of a condemned inan. The utmost in procedural regularity must be accorded him during the course of his trial and any subsequent appeals. Once these are exhausted, few would argue that the importance of his interest entitles him to a formalized hearing im his appeal for executive clemency-which turns on unreviewed discretion. ${ }^{143}$ It is the discretionary nature of the decision, and not its importance to the individual, that determines whether or not procedural safeguards are appropriate.

Moreover, even if "importance" were somelow related to the need for procedural due process protection, the difficulty of gauging it would nake that approach either unadministerable or simply an excuse for imposing procedural protections in every case. The issue of plaintiff Roth's reputation interest provides an example. Under the Goldberg importance approach, the Court in Roth would have liad to balance "the extent to which [Roth] may be 'condemned to suffer grievous loss" " as a result of the injury to his reputation against "the governmental interest in summary adjudication."144 How does one balance the importance of preserving administrative freedom and discretion

142. Id. at 13.

143. See Grey, Procedural Faimess and Substantive Rights, in 18 Nomos, DUE Process 182, 189 (J. Pennock \& J. Chapman eds. 1977).

144. Goldberg v. Kelly, 397 U.S. 254, 262-63 (1970). 
against "a blemish [to Roth's reputation] that turns into a perinanent scar and effectively limits any chance [he] has of being rehired as a teacher . . ."145 In any ad hoc balancing approach, individual injuries will always appear more pressing than institutional benefits. Where the only touchstone is the Court's assessment of "the importance" of the imdividual's interest, virtually all government activity would sooner or later be subjected to prior hearing requirements, without regard to the effect this might ultimately have on the substantive bases upon which the decisions are made. In contrast, by separating the substantive question from the procedural one, the Roth approach makes it possible for the Court to weigh individual and institutional interests at comparable levels of abstraction, and to reach a more appropriate resolution of the conflicting policy considerations presented.

\section{CONCLUSION}

The Supreme Court's decisions in Board of Regents v. Roth and Perry v. Sindermann outline a workable approach to the difficult problems of defining "property" for the purposes of deternining whether due process is required to protect them. Roth and Perry are consistent with the history of the Supreme Court's treatment of property, its creation, and its protection. The Roth-Perry doctrine is also consistent with the institutional structure of our government: sovereign states define the terms of the rights they dispense and recognize, but federal courts are the ultimate arbiters of the process the Constitution requires. Such consistency clearly recommends the doctrine and bodes well for its continumg durability.

145. Roth, 408 U.S. at 585 (Douglas, J., dissenting). 